\title{
36. LABORATORY AND WELL-LOG VELOCITY AND DENSITY MEASUREMENTS FROM THE ONTONG JAVA PLATEAU: NEW IN-SITU CORRECTIONS TO LABORATORY DATA FOR PELAGIC CARBONATES ${ }^{1}$
}

\author{
Jozsef Urmos, ${ }^{2}$ Roy H. Wilkens, ${ }^{3}$ Franck Bassinot, ${ }^{4}$ Mitchell Lyle, ${ }^{5}$ \\ Janice C. Marsters, ${ }^{3}$ Larry A. Mayer, ${ }^{6}$ and David C. Mosher ${ }^{7}$
}

\begin{abstract}
During Ocean Drilling Program Leg 130, sonic velocity and bulk density/porosity well logs were measured in five separate holes drilled through the sequence of pelagic carbonate oozes, chalks, and limestones that comprise the thick, continuous sedimentary cover on the Ontong Java Plateau. An internally consistent and continuous suite of shipboard laboratory velocity and sediment physical properties measurements were made from the top of each hole down through the entire logged interval. Because of the high quality of the data, extensive overlap of $500 \mathrm{~m}$ or more between the $\log$ and laboratory measurements at each hole, and the homogeneous nature of the sediments, we have been able to compare laboratory and in-situ log measurements in detail and to evaluate factors that alter laboratory data from their in-situ values.

For measurements of bulk density and porosity, differences between laboratory and in-situ log measurements are very small and remain constant over the entire range of depths studied. We have applied a simple hydraulic rebound correction to the laboratory data that compensates for pore fluid expansion after removal of a sediment sample from in-situ conditions. The small, correctable differences between the laboratory and log data imply that mechanical rebound is significantly less than previous estimates (maximum near 5\%) of rebound in pelagic carbonates. Furthermore, porosity rebound cannot be used to correct laboratory sonic velocity measurements to in-situ values. Such a rebound correction implicitly requires that laboratory and in-situ data must occupy identical fields on velocity-porosity crossplots. This condition is not met for the Ontong Java Plateau results because laboratory and in-situ logging data occupy distinct trends with little overlap between the two types of measurement. Mechanical rebound in pelagic carbonates cannot be used to correct either laboratory porosity or velocity measurements to in-situ values. The complex porosity systematics of these carbonates resulting from varying abundances of hollow foraminifer grains precluded use of an empirical correction derived from the log porosity and velocity data.

Laboratory sonic velocity measurements can be corrected to in-situ values at all of the Ontong Java Plateau sites using a depth-based function derived from downhole differences between log and laboratory velocities in Hole 807A. The applicability of the depth correction implies that the effect of overburden pressure reduction on sediment elastic moduli is the most significant factor affecting laboratory velocity measurements. The depth correction to laboratory velocity measurements appears to be generally applicable to pelagic carbonate oozes and chalks of the Ontong Java Plateau, regardless of depositional depth or sediment age.
\end{abstract}

\section{INTRODUCTION}

The thick, continuous sequence $(>1 \mathrm{~km})$ of sediments on the Ontong Java Plateau in the western equatorial Pacific Ocean almost solely consists of homogeneous pelagic carbonates diluted by minor amounts $(<10 \%)$ of biogenic silica. The Ontong Java Plateau sediments constitute a high-quality repository of information for studies of the properties of carbonate sediments free from complications introduced by other intermixed sediment types. Surficial sediments on the Ontong Java Plateau have been studied in great detail, and variations in porosity, density, grain size, sonic velocity, and other physical properties of these sediments as well as interrelationships between the various properties have been examined over much of the plateau (Johnson et al., 1977; Berger et al., 1977). Hamilton et al. (1982) summarized previous work on the Ontong Java Plateau surficial sediments and evaluated such factors as dissolution, dilution,

'Berger, W.H., Kroenke, L.W., Mayer, L.A., et al., 1993. Proc. ODP, Sci. Results, 130: College Station, TX (Ocean Drilling Program).

${ }^{2}$ Oceanography Department, School of Ocean and Earth Science and Technology, University of Hawaii, 1000 Pope Road, Honolulu, HI 96822, U.S.A.

${ }^{3}$ Institute of Geophysics, School of Ocean and Earth Science and Technology, University of Hawaii, 2525 Correa Road, Honolulu, HI 96822, U.S.A.

${ }^{4}$ Laboratoire de Géologie du Quaternaire, CNRS Luminy-Case 907, 13288 Marseille Cedex 9, France.

${ }^{5}$ Borehole Research Group, Lamont-Doherty Geological Observatory, Palisades, NY 10964, U.S.A.

${ }^{6}$ Ocean Mapping Group, Department of Surveying Engineering, University of New Brunswick, P.O. Box 4400, Fredericton, New Brunswick E3B 5A3, Canada.

${ }_{7}^{7}$ Department of Oceanography, Dalhousie University, Halifax, Nova Scotia B3H 4J1, Canada. winnowing, and intraparticle porosity from hollow foraminifers that affect the physical and elastic properties of pelagic carbonate sediments. Many of these same causative factors have been evaluated in studies of the nature and origin of acoustic reflectors that define a distinctive layer-cake seismic stratigraphy characteristic of sediments in the central Ontong Java Plateau (Berger et al., 1977; Berger and Mayer, 1978).

Sediments from the subsurface of the Ontong Java Plateau were recovered during Deep Sea Drilling Project (DSDP) Legs 7, 30, and 89. Shore-based laboratory studies by Milholland et al. (1980) and Kim et al. (1985) have evaluated changes in compressional and shear wave velocities, density, porosity, and attenuation in relation to depth, lithology, pore geometry, and burial diagenesis. Geophysical well logs were first obtained from Ontong Java Plateau sediments during Leg 89 at Site 586. Fulthorpe et al. (1989) examined in detail the density and sonic logs from Site 586 and found good agreement with depth between $\log$ and seismic velocities derived from sonobuoy surveys on the Ontong Java Plateau (Johnson et al., 1978) but poor agreement with laboratory velocity measurements. Fulthorpe et al. (1989) concluded that logging data give a reliable measure of in-situ sediment properties and that laboratory measurements are significantly affected by porosity rebound and reduction of sediment elastic moduli.

The quantity and quality of information and sediments recovered from the subsurface of the Ontong Java Plateau were increased substantially during Ocean Drilling Program (ODP) Leg 130. Nearly $4800 \mathrm{~m}$ of pelagic carbonate sediments were recovered from 16 holes drilled at 5 sites on the northeastern margin of the Ontong Java Plateau (Kroenke, Berger, Janecek, et al., 1991). Sediments recovered consist of Pleistocene to upper Eocene oozes and chalks as well as Eocene to 
Cretaceous limestones, cherts, and shales in sections directly overlying basaltic basement. Well logs were obtained at Leg 130 Holes 803D, 805C, 806B, 807A, and 807C.

In evaluating changes that affect physical properties measurements between in-situ and laboratory conditions, Hamilton (1965, 1976 ) identified (1) temperature changes, (2) pressure reduction, (3) decrease in sediment rigidity, and (4) mechanical porosity rebound as the major factors that will affect laboratory measurements. The excellent suite of in-situ log and laboratory measurements obtained during Leg 130 have allowed us to evaluate which of these factors significantly affect laboratory physical properties measurements of these pelagic carbonates. Density and porosity logs were used to evaluate the magnitude of mechanical porosity rebound in laboratory measurements and, in addition, to assess the validity of using porosity rebound as a means to correct laboratory velocities. Because of the importance of accurate determinations of in-situ sonic velocities for correlating seismic stratigraphies with geologic events identified in boreholes, we have used laboratory and log data to derive an empirical correction for converting laboratory velocity measurements to in-situ values.

\section{METHODS}

\section{Logging Tools}

Logging data used in this study were collected using the Schlumberger lithodensity tool (HLDT) and long-spaced sonic tool (LSS). More detailed descriptions of the geophysical logging tools and procedures used during Leg 130 are given in Kroenke, Berger, Janecek, et al. (1991). The HLDT data are essentially a measure of the electron density of the formation. A radioactive source in the tool emits gamma rays that undergo Compton scattering because of interactions with electrons in the formation. A detector at a fixed distance from the source counts the scattered gamma rays, which are proportional to the electron (and so bulk) density of the formation. To negate the effects of borehole fluid, the gamma source and detectors are pressed against the borehole wall by a caliper arm hydraulically operated from the surface once the tool is set to begin the logging run.

The LSS consists of two acoustic sources (separated by $0.61 \mathrm{~m}$ ) with center frequencies of approximately $12 \mathrm{kHz}$ and two similarly separated receivers. Sources and receivers are aligned on the tool with a $2.44-\mathrm{m}$ separation between the nearest source-receiver pair. Travel paths from the near source to the two receivers are 2.44 and $3.05 \mathrm{~m}$, whereas far-source receiver paths are 3.05 and $3.66 \mathrm{~m}$. Traveltimes of the compressional energy to each of the receivers is electronically identified and recorded. Compressional wave velocity is determined by dividing the receiver separation by the difference in traveltimes at the two receivers. One velocity is determined from the near-source signal and one from the far-source signal. In environments where the formation around the borehole wall has been damaged, longer spacing often will yield better results than short spacing because the sonic energy penetrates farther into the formation. Data used in this study are from the far-source receiver pair, although for most of the Leg 130 logs no appreciable difference was present between the two velocity logs.

Although no porosity logs were recorded during Leg 130, a porosity log was derived from the density logging data. The porosity $\log$ was calculated by rearranging the equation,

$$
\rho_{b}=\phi \rho_{w}+(1-\phi) \rho_{g},
$$

to solve for porosity $(\phi)$ from sediment bulk density $\left(\rho_{b}\right)$, as measured by the density $\log$, density of mineral grains $\left(\rho_{g}\right)$, and density of interstitial water $\left(\rho_{w}\right)$. Because sediments on the Ontong Java Plateau are mineralogically homogeneous pelagic carbonates, the density of calcite $\left(2.72 \mathrm{~g} / \mathrm{cm}^{3}\right)$ is a reasonable grain density. The in-situ density of interstitial fluids as a function of temperature, pressure, and salinity was calculated from the equation of state for seawater (Millero et al., 1980;
Millero and Poisson, 1981). In our estimates of in-situ seawater density, a constant salinity of $35 \%$ was assumed at the seafloor and within the borehole. Seafloor water temperatures were estimated using hydrographic data from a GEOSECS latitudinal transect in the western equatorial Pacific (Broecker et al., 1982). Downhole temperatures were obtained using an estimated geothermal gradient of $20^{\circ} \mathrm{C} / \mathrm{km}$. Because the density of seawater at the bottom of Hole $807 \mathrm{C}$, the deepest hole, differs by $<0.2 \%$ from density at the seafloor, the density of seawater at the top of a hole was used for the downhole interstitial water density. A porosity log calculated in this way provides a reasonably good estimate of overall porosity trends in a particular hole, but it will prove unreliable for siliceous intervals, ash layers, or other minor lithologies with grains densities differing from that of calcite.

All of the data from the borehole logs were smoothed using a running average over a $1.0-\mathrm{m}$ window, with values calculated at $0.5-\mathrm{m}$ intervals. This was done to reduce the bulk of the data set to a manageable size and to help make comparisons of the log and laboratory data by minimizing the effects of outliers in the logs. The logging data were originally reported at $0.152-\mathrm{m}(6-\mathrm{in}$.) intervals.

\section{Sonic Velocity}

Compressional wave velocities of sections of recovered core were measured using a modification of the pulse transmission technique described by Boyce (1976a). The time of flight of an ultrasonic ( 500 $\mathrm{kHz}$ ) signal between two transducers of known separation was measured electronically and velocity was calculated. In soft sediments a digital sound velocimeter (DSV) (Mayer et al., 1987) was employed. The DSV transducers were arrayed in two orthogonal sets that were inserted into the soft sediment of the split core. Velocities were measured in vertical (parallel to the core axis) and horizontal (normal to the core axis) orientations. Arrival times were picked from digitized waveforms delivered to a dedicated personal computer.

Compressional wave velocities of indurated sediments were measured in the Hamilton Frame velocimeter (Boyce, 1976a). Measurements were made across surfaces cut parallel and perpendicular to the axis of the core whenever possible. DSV electronics were used to time the ultrasonic pulses. The distance between the Hamilton Frame transducers was calculated from a slide wire resistor attached to the closure mechanism of the frame.

\section{Bulk Density}

Density and porosity determinations were made on samples obtained from virtually every location in the cores where velocity was measured. Saturated weights of samples were measured immediately after they were taken from the cores. After being dried in an oven at $110^{\circ} \mathrm{C}$ for $24 \mathrm{hr}$, the samples were reweighed and the volume of dry material was measured with a helium displacement pycnometer. The salt-corrected volume of a wet sample was calculated by adding the volume of water evaporated (assuming $1.00 \mathrm{~g} / \mathrm{cm} 3$ density) during drying. Bulk density was calculated by dividing the wet weight of the sample by the calculated wet volume. Porosity was calculated by dividing the lost water volume (i.e., void volume) by the total volume of the sample. These methods and calculations are described in greater detail in Kroenke, Berger, Janecek, et al. (1991).

\section{DATA}

\section{Leg 130 Summary}

During Leg 130 nearly $4800 \mathrm{~m}$ of pelagic carbonate sediments were recovered from 16 holes drilled at 5 sites on the northeastern margin of the Ontong Java Plateau (Fig. 1) (Kroenke, Berger, Janecek, et al., 1991). Four of the sites (803-806) were drilled along a depth transect (2520-3410 m water depth) down the eastern flank of the plateau near the equator. Site 807 was drilled on the northern margin of the Ontong 
Java Plateau at a location selected to recover as complete a Paleogene sediment section as possible and to sample a deep basement section. The generalized stratigraphy of sediments as recovered consists of Pleistocene to upper Eocene nannofossil oozes and chalks, containing variable amounts of foraminifers, underlain by upper/middle Eocene to Cretaceous limestones that are silicified in some intervals and contain chert nodules and minor chert layers. The basal Cretaceous sediment sections are variable in composition and consist of limestones or claystones/siltstones. Cretaceous basaltic basement was reached at 630.4 mbsf (meters below seafloor) in Hole 803D and at $1369.7 \mathrm{mbsf}$ in Hole $807 \mathrm{C}$.

Our detailed discussion of the Leg 130 laboratory physical properties measurements and logging data will focus primarily on results obtained from the carbonate oozes and chalks recovered from Site $807\left(3^{\circ} 36.4^{\prime} \mathrm{N}\right.$, $\left.156^{\circ} 37.5^{\prime} \mathrm{E}\right)$ in $2805 \mathrm{~m}$ of water and Site $805\left(1^{\circ} 13.7^{\prime} \mathrm{N}, 160^{\circ} 31.8^{\prime} \mathrm{E}\right)$ in $3188 \mathrm{~m}$ of water. Other Leg 130 data were examined from Site 803 $\left(2^{\circ} 26.0^{\prime} \mathrm{N}, 160^{\circ} 32.5^{\prime} \mathrm{E}\right)$ in $3410 \mathrm{~m}$ of water and Site $806\left(0^{\circ} 19.1^{\prime} \mathrm{N}\right.$, $159^{\circ} 21.7^{\prime} \mathrm{E}$ ) in $2520 \mathrm{~m}$ of water (Kroenke, Berger, Janecek, et al., 1991). In addition, a composite of data from DSDP Sites 289/586 was also considered. Site $289\left(0^{\circ} 29.92^{\prime} \mathrm{S}, 158^{\circ} 30.69^{\prime} \mathrm{E}\right)$ was drilled during DSDP Leg 30 about $140 \mathrm{~km}$ southwest of Site 805 near the center of the Ontong Java Plateau at a water depth of $2224 \mathrm{~m}$ (Shipboard Scientific Party, 1975). During DSDP Leg 89, Site 586 was drilled next to Site 289 and logged to just over 600 mbsf (Shipboard Scientific Party, 1986).

\section{Log Data}

The primary logging results that will be examined in detail in this paper are from the velocity and bulk density logs. The porosity log data were calculated from the density log as outlined above. Logs were obtained during Leg 130 from Holes 803D, 805C, 806B, 807A, and 807C (Kroenke, Berger, Janecek, et al., 1991), as well as during DSDP Leg 89 at Site 586 (Shipboard Scientific Party, 1986). Well-log data were measured over the interval from about 600 to $100 \mathrm{mbsf}$ in

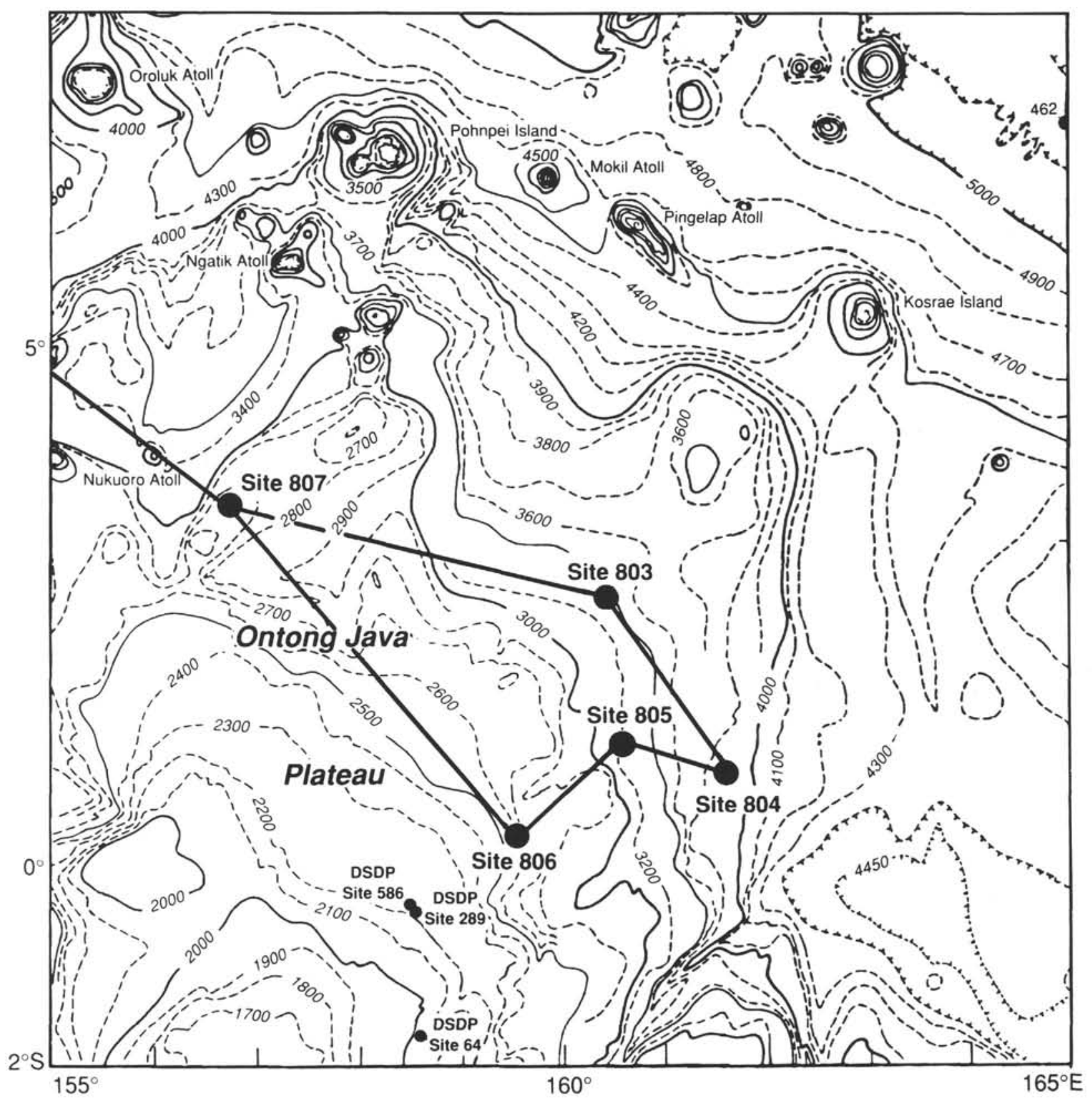

Figure 1. Locations of Leg 130 and previous DSDP drilling sites on the northeastern portion of the Ontong Java Plateau. Bathymetric contours are in meters. 
Holes 803D and $805 \mathrm{C}$ and from 725 to 100 mbsf in Hole 806B. Excellent logging data were obtained at Site 807 where logs were run from 820 to 89.6 mbsf in Hole $807 \mathrm{~A}$ and from 1500 to 350 mbsf in Hole 807C. Well-log data at Site 586 were collected from about 610 to 80 mbsf. Logs at all of the sites show generally similar trends with depth in the carbonate oozes and chalks.

Although logs were obtained from Hole 807A and 807C, we have limited our discussion to the Hole 807A log data because of the more complete coverage of the oozes and chalks and because logs from both holes are nearly identical. The density log shows an increase of bulk density from $1.6 \mathrm{~g} / \mathrm{cm}^{3}$ at $100 \mathrm{mbsf}$ to $1.8 \mathrm{~g} / \mathrm{cm}^{3}$ at $400 \mathrm{mbsf}$, except for the interval from 220 to 380 mbsf where density values are offset by about $0.05 \mathrm{~g} / \mathrm{cm}^{3}$ below the overall trend in the data (Fig. 2). Density values increase to a local maximum slightly above 1.9 $\mathrm{g} / \mathrm{cm}^{3}$ at about $720 \mathrm{mbsf}$ and then gradually decrease by about 0.06 $\mathrm{g} / \mathrm{cm}^{3}$. Below $780 \mathrm{mbsf}$, density values exhibit greater variability because of carbonate and silica diagenesis and reductions in porosity. Site 807 velocity log data generally increase from near $1.65 \mathrm{~km} / \mathrm{s}$ at $80 \mathrm{mbsf}$ to about $2.5 \mathrm{~km} / \mathrm{s}$ at $700 \mathrm{mbsf}$. Between 300 and $450 \mathrm{mbsf}$, a slightly greater rate of increase in velocity values occurs, relative to the overall trend, followed by a flatter interval to $600 \mathrm{mbsf}$. Velocities remain constant at about $2.5 \mathrm{~km} / \mathrm{s}$ down to the chalk/limestone transition, near $980 \mathrm{mbsf}$, below which the velocity data become much noisier and reach maxima of $4.0-4.5 \mathrm{~km} / \mathrm{s}$.

The velocity and bulk density logs recorded from Hole 803D correlate better than do the other Ontong Java Plateau sites (Fig. 2). Between 200 and 260 mbsf the log densities step up sharply from 1.6 to nearly $1.9 \mathrm{~g} / \mathrm{cm}^{3}$; across the same interval the velocity log shows more variation, but an overall increase of velocity from about 1.7 to $2.0 \mathrm{~km} / \mathrm{s}$ occurs. Following this transition in the log properties, densities remain nearly constant and velocities gradually increase to about $2.3 \mathrm{~km} / \mathrm{s}$ over the interval down to $520 \mathrm{mbsf}$. Velocity and density increase at greater rates over the $520-600 \mathrm{mbsf}$ interval where values increase from about 2.3 to $2.6 \mathrm{~km} / \mathrm{s}$ and from about 1.9 to 2.3 $\mathrm{g} / \mathrm{cm}^{3}$, respectively. The higher gradients in the logs near the base of Hole 803D may be related to the onset of silica diagenesis (Kroenke, Berger, Janecek, et al., 1991).

In Hole $805 \mathrm{C}$, log densities increase from about 1.7 to $1.8 \mathrm{~g} / \mathrm{cm}^{3}$ between 120 and 380 mbsf; below this interval the rate of increase of density with depth becomes slightly higher, reaching values near 2.0 $\mathrm{g} / \mathrm{cm}^{3}$ at $600 \mathrm{mbsf}$ and the amplitudes of the variations become slightly greater (Fig. 2). The Hole $805 \mathrm{C}$ velocity log shows a flat interval from 100 to $160 \mathrm{mbsf}$ where velocities are about $1.65-1.70 \mathrm{~km} / \mathrm{s}$ followed by a constant increase in velocity to near $2.5 \mathrm{~km} / \mathrm{s}$ at $600 \mathrm{mbsf}$.

\section{Laboratory Data}

The laboratory physical properties profiles show similar depth trends at all of the Ontong Java Plateau sites. Bulk density values increase from $1.5 \mathrm{~g} / \mathrm{cm}^{3}$ near the seafloor to about $1.9 \mathrm{~g} / \mathrm{cm}^{3}$ at the transition from chalk to limestone (Fig. 2). Density values increase uniformly with depth, with only minor local variations from the overall trend of increase until limestones are encountered (1098 mbsf at Site 807 ). Limestone density values are more variable and may range up to $2.6 \mathrm{~g} / \mathrm{cm}^{3}$. Depth trends opposite those observed for bulk densities are found in the porosity measurements. Porosities, near 0.70 at the surface, decrease gradually to $0.45-0.50$ in the lowermost chalks and become more variable in limestones, where porosities are as low as $0.05-0.10$.

Velocity data exhibit different patterns of variation with depth than do bulk density and porosity values. Velocities start at about $1.5 \mathrm{~km} / \mathrm{s}$ near the seafloor and increase slightly to about $1.6 \mathrm{~km} / \mathrm{s}$ at the transition from carbonate ooze to chalk (Fig. 2). Velocity measurements in oozes generally do not vary by much more than $0.1 \mathrm{~km} / \mathrm{s}$ about the average. Velocities increase more sharply in chalks and are much more variable. In the upper $100-150 \mathrm{~m}$ of chalk, velocities increase from near $1.6 \mathrm{~km} / \mathrm{s}$ to about $2.0 \mathrm{~km} / \mathrm{s}$, after which velocities may increase slightly $(<0.5 \mathrm{~km} / \mathrm{s})$ until the transition to limestones, which have more scattered velocities between 3.5 and $5.0 \mathrm{~km} / \mathrm{s}$. Calcium carbonate contents for all sediments recovered are consistently quite high. Carbonate values generally increase slightly from about $85 \%$ to $90 \%$ at the seafloor to values of $90 \%-95 \%$ by about 50 mbsf; below this depth calcium carbonate contents remain above $90 \%$ except for localized ash layers, siliceous intervals, and chert layers where carbonate values may drop by as much as $50 \%$.

\section{DENSITY/POROSITY REBOUND}

The systematic differences between the in-situ log and laboratory density and porosity measurements observed at Site 807 are typical of the other Ontong Java Plateau sites and are indicative of the need for a correction to adjust laboratory measurements to in-situ conditions. Based on previous studies (Hamilton, 1976, 1979), it has been commonly assumed that mechanical rebound (expansion) of sediment porosity resulting from removal of overburden pressure on the sediment is the primary factor to be accounted for when correcting laboratory measurements to in-situ values. Hamilton (1976) derived an empirical rebound function for carbonates at depth below the seafloor based on laboratory consolidation tests of marine sediments containing $30 \%$ or more calcium carbonate. The magnitude of the mechanical rebound correction to laboratory porosity ranges from zero at the seafloor to a maximum of approximately $5 \%$ at $500 \mathrm{mbsf}$. The rebound function is also consistent with assumed trends of decreasing rebound expected at depths greater than 500 mbsf (Shipley, 1983).

Because the laboratory and log measurements of bulk density and porosity are already in remarkably close agreement with each other (Figs. 2 and 3), the magnitude of any corrections to the laboratory measurements will not have to be very large. Inspection of the crossplots in Figure 3 illustrates that the raw laboratory bulk densities and porosities are offset by a small, nearly constant amount from the $\log$ measurements over the entire range of property values. This implies that only a small, constant correction is necessary to bring the laboratory and $\log$ results into agreement.

To understand the nature of differences between log and laboratory data better, we used the mechanical rebound correction to carbonate sediment porosity (Hamilton, 1976) to adjust the Hole 807A laboratory porosity measurements. These new porosities were then used to calculate a mechanical rebound corrected bulk density using Equation 1. These rebound-corrected laboratory measurements are compared with the in-situ logging results in Figures $4 \mathrm{~A}$ and 5. It is immediately obvious from these figures that the mechanical rebound correction is far too large. At 500 mbsf, the rebound-corrected bulk density is nearly $0.1 \mathrm{~g} / \mathrm{cm}^{3}$ greater than the log bulk density, and the corrected laboratory porosity underestimates the log porosity by more than $5 \%$ (Fig. 5). By 100 mbsf, where the first logging results are available, mismatches between the rebound corrected laboratory measurements and the logs are already significant and become progressively greater downhole (Fig. 5). The mechanical rebound correction derived by Hamilton (1976) for carbonate sediments does not appear to be applicable to the pelagic carbonates from Hole 807A, or to the other Ontong Java Plateau sites.

Other studies have similarly found that mechanical rebound in pelagic carbonates is less than predicted from the empirical rebound correction obtained by Hamilton (1976). Laboratory consolidation tests on Ontong Java Plateau sediments recovered during Leg 130 have yielded estimates of mechanical porosity rebound of $<0.1 \%$ over a 1000-m equivalent depth range (Lind, this volume) and an average maximum near 3\% at an equivalent depth of $1200 \mathrm{mbsf}$ (Marsters and Manghnani, this volume). Consolidation tests on pelagic carbonates recovered during Leg 115 have also revealed negligible porosity rebound during unloading of laboratory samples (Hurley and Hempel, 1990). Comparisons of $\log$ and laboratory data from Leg 114 Site 704 have revealed that laboratory porosity and bulk density data are equivalent to in-situ values (Nobes et al., 1991). (We note that in 
contrast with pelagic carbonates, mechanical rebound correction (Hamilton, 1976) of laboratory measurements from terrigenous sediments was found to yield values that agree reasonably well with log data (Jarrard et al., 1989).

The porosity rebound correction represents an attempt to adjust for mechanical expansion that the sediment mineral matrix undergoes upon transferral from in-situ conditions to the laboratory. Corrections to account for thermal and pressure effects that affect interstitial fluids are small and have generally not been applied (Hamilton, 1971). We applied corrections to adjust for hydraulic rebound of the pore fluids by an estimation of the changes in fluid density between the borehole and the laboratory. In-situ fluid density was obtained by using the method outlined above in the porosity log calculation. Once the density of seawater at the top of a particular hole has been determined, laboratory porosities and densities can be corrected for expansion of sediment pore waters from in-situ values. To correct laboratory porosities, porosity data are simply multiplied by the ratio of laboratory and in-situ seawater densities $\left(\rho_{\mathrm{lab} /} \rho_{\mathrm{is}}\right)$ to obtain an adjusted fluid volume, and porosity is then recalculated using the original grain volume measurement. Mineral volume changes are not considered because they are insignificant relative to the fluid volume changes over the range of pressures and temperatures encountered in the Ontong Java Plateau boreholes (Skinner, 1966). Laboratory bulk densities are recalculated (Eq. 1) to in-situ conditions using corrected laboratory porosities and in-situ seawater density.

Results of the hydraulic rebound correction to laboratory densities and porosities from Hole 807A are illustrated in Figures 4B and 5. Over the depth interval for which log and laboratory densities and porosities are available, corrections to the laboratory measurements yield excellent agreement with large-scale variations in the logs (Fig. 5 ). This excellent match between corrected laboratory and log data is also seen in crossplots (Fig. 4B) where data are centrally clustered about the 1:1 relationship between the two measurement types.

Uncorrected and hydraulic rebound corrected laboratory densities and porosities are illustrated in crossplots of laboratory and log results for Hole 805C (Fig. 6) and for Sites 289/586 (Fig. 7). At these sites, relationships between laboratory and log data are the same as at Hole 807A (Fig. 4B). Raw laboratory data already agree reasonably well with the logs; densities are slightly lower and porosities slightly higher relative to the logs. Application of the hydraulic rebound correction to the laboratory measurements eliminates the small offsets to give an excellent match with the log densities and porosities. Also of importance is the fact that older data from Sites 289/586, recorded with different logging tools, behave similarly to Leg 130 data, making it highly unlikely that any hidden systematic errors may be biasing the Leg 130 or earlier results.

From the data at hand, none of the sites examined (see Figs. 3-7) show any observable evidence for significant mechanical rebound of the sediment mineral matrix in laboratory measurements of bulk density and porosity. Use of an empirical rebound function (Hamilton, 1976) to "correct" laboratory data from pelagic carbonates produces a match with the logging results that is substantially worse than with uncorrected laboratory data. The mechanical rebound correction also introduces trends with depth (Fig. 5) and in density and porosity crossplots (Fig. 4A) that are not supported by logging data. Thus, it appears that in pelagic carbonate sediments from the Ontong Java Plateau rebound of the sediment mineral matrix is not evident in comparisons of $\log$ and laboratory measurements of density and porosity. A hydraulic-rebound correction accounting primarily for pressure- and temperature-induced changes in the density of seawater between borehole and laboratory conditions is sufficient to reconcile already minor differences between laboratory and in-situ log measurements. An important implication of this apparent lack of rebound in the Ontong Java Plateau carbonate sediments concerns the use of porosity rebound to correct laboratory sonic velocity measurements to in-situ conditions in a borehole.

\section{POROSITY-VELOCITY RELATIONS}

The primary method used to correct laboratory measurements of sonic velocities in marine sediments has involved the use of porosity rebound to adjust velocity measurements to "in-situ" values (Boyce, 1976b, 1980; Shipley, 1983; Mayer et al., 1985; Hempel et al., 1989). Key to the porosity rebound correction of laboratory velocity data are velocity-porosity crossplots that are used to establish the relationship between the two sediment properties. Knowing how velocity varies with porosity, the change in porosity to in-situ values estimated from the mechanical rebound correction can be translated into an apparent change in velocity, which is then added to the laboratory measurement to give an in-situ value. The evident lack of measurable rebound of the sediment mineral matrix in laboratory measurements of density and porosity from pelagic carbonates on the Ontong Java Plateau brings into question the general applicability of the rebound correction to laboratory velocities for these types of sediments.

Crossplots of the Hole 807A laboratory and log measurements of velocity and porosity are illustrated in Figure 8. Laboratory velocities are those measured normal to the core axis. Also shown for reference in Figure 8 are the velocity-porosity relationships of Wood (1941) and Wyllie et al. (1956). Wood's equation describes sediments that are assumed to consist of a suspension of mineral grains and fluid that has no rigidity. Wyllie's equation is a function for describing sedimentary rocks having complete rigidity and having sonic velocities that are the time average of mineral and fluid velocities. The Wood and Wyllie equations roughly define the lower and upper boundaries, respectively, of potential sonic velocity variations in sediments.

Logging results from Hole $807 \mathrm{~A}$ lie on a diagonal trend that passes between the Wood and Wyllie curves (Fig. 8). At the highest porosity values in the carbonate oozes $(\sim 0.68)$, velocities approach to within about $0.15 \mathrm{~km} / \mathrm{s}$ of the Wood curve. In the lowermost chalks logged in Hole $807 \mathrm{~A}$, data begin to cluster along the Wyllie curve at porosities near 0.50. Deeper chalks and limestones logged in Hole 807C (not shown in Fig. 8) continue the trend from Hole 807A and cluster near and above the Wyllie curve at porosities below 0.50 . High-porosity excursions above the average trend of the data appear to result from varying abundances of large, intact foraminifers; in terms of velocity, these hollow foraminifers behave as solid spheres such that resulting changes in sediment porosity are not reflected in changes of velocity (Hamilton et al., 1982; Bachman, 1984).

The Hole $807 \mathrm{~A}$ laboratory results fall on a trend substantially different from those observed for the log data (Fig. 8). The greatest difference in behavior occurs for data from the carbonate oozes. These laboratory results constitute a cluster that parallels the Wood curve, at velocities about $0.05 \mathrm{~km} / \mathrm{s}$ greater, between porosities of 0.60 and 0.70 . In contrast, results from the interval logged in the lower $200 \mathrm{~m}$ of the oozes fall along a distinct trend away from the Wood curve, which is also consistent with the trend of log data from the underlying chalks. Laboratory measurements from the chalks, mostly below about 0.60 porosity, exhibit a great deal of scatter and fall on a trend, roughly subparallel to the log data (Fig. 8).

The significantly different trends in laboratory and log velocityporosity crossplots are of fundamental importance to the application of a porosity rebound correction to laboratory velocity measurements. The major-and not always stated-assumption underlying the porosity rebound correction of velocity is that the trend of raw velocity and porosity data in velocity-porosity space is the same as for these properties in situ. Examination of Figure 8 shows that there is virtually no overlap whatsoever between the laboratory and in-situ log data. This disparity means that porosity rebound cannot be validly applied to correct laboratory sonic velocity measurements from pelagic carbonate sediments such as those on the Ontong Java Plateau.

The Hole 807A log and laboratory data suggest that, of factors affecting the physical properties of a sediment between in-situ and 

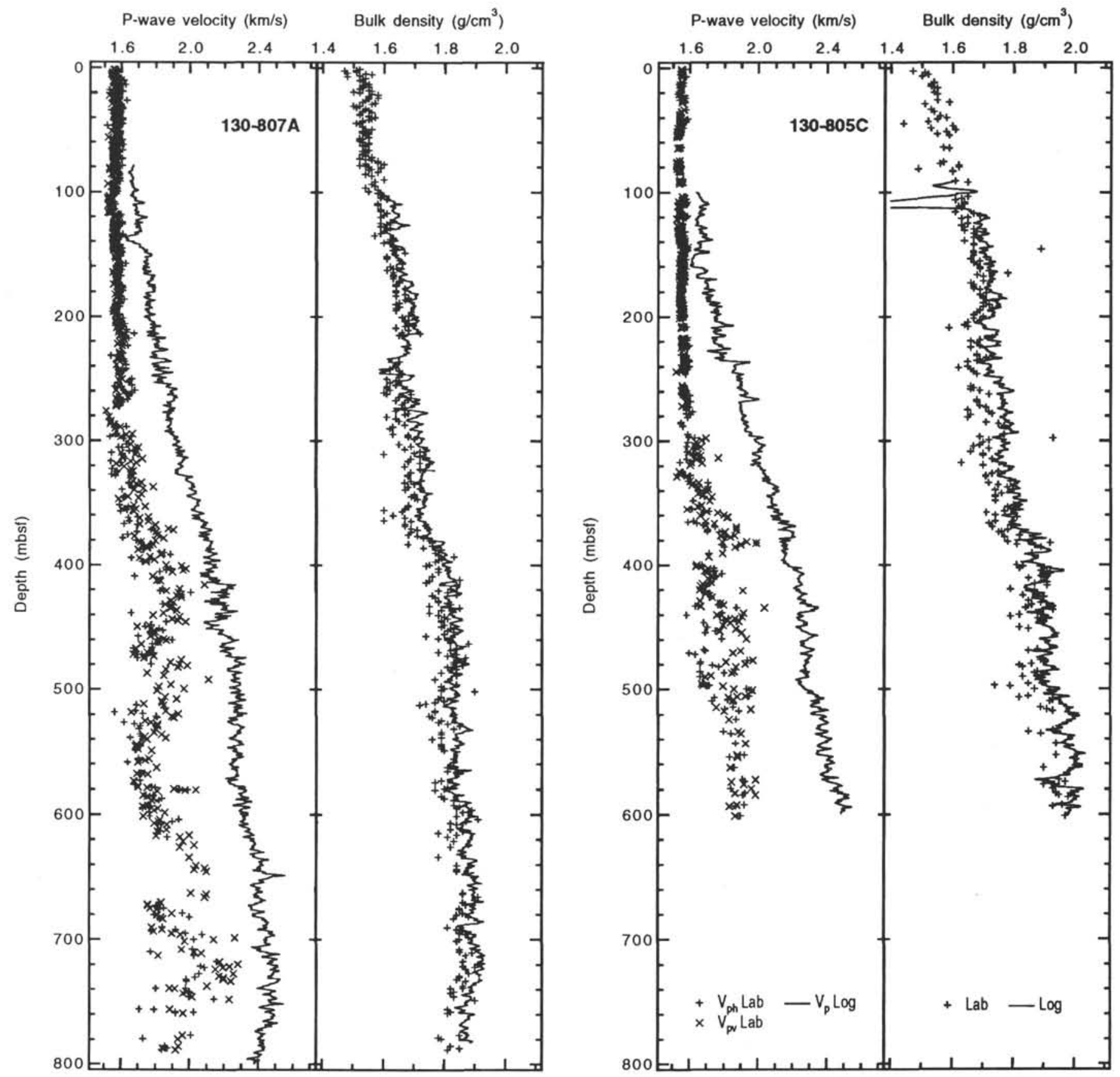

Figure 2. Downhole variations in log and shipboard laboratory measurements of sonic velocity and bulk density for sites on the Ontong Java Plateau. Laboratory velocities are shown for horizontal $\left(V_{p h}\right)$ and vertical $\left(V_{p v}\right)$ measurements relative to the vertical core axis.

laboratory conditions, changes in elastic moduli as a consequence of the removal of overburden pressure are of greatest significance for interpreting discrepancies between laboratory and in-situ log velocities. In previous studies examining the problem of correcting laboratory data to in-situ conditions in marine carbonates and other sediment types (Boyce, 1976b; Hamilton, 1979; Mayer et al., 1985; Hempel et al., 1989), porosity rebound was considered to be the primary factor affecting laboratory velocity measurements and changes in elastic moduli were considered to have a minor but indeterminate effect on sonic velocity.

Changes in elastic moduli must affect laboratory velocity measurements in pelagic carbonates, as Figure 8 illustrates and as com- parisons of downhole trends also show (Fig. 2). Differences between laboratory and log measurements of bulk density and porosity are small and constant throughout the entire depth range. On the other hand, relative velocity differences are much greater and increase with depth; this is especially evident in the carbonate oozes above 300 mbsf. Were porosity rebound the primary factor affecting laboratory velocities, then the differences with the velocity log should similarly be small and constant with depth. Furthermore, in the oozes, the logs show a steadily increasing sediment velocity with depth, but the laboratory velocity measurements are virtually constant. This pattern is consistent with reductions in sediment elastic moduli expected from the removal of overburden pressure. The oozes are highly sensitive 


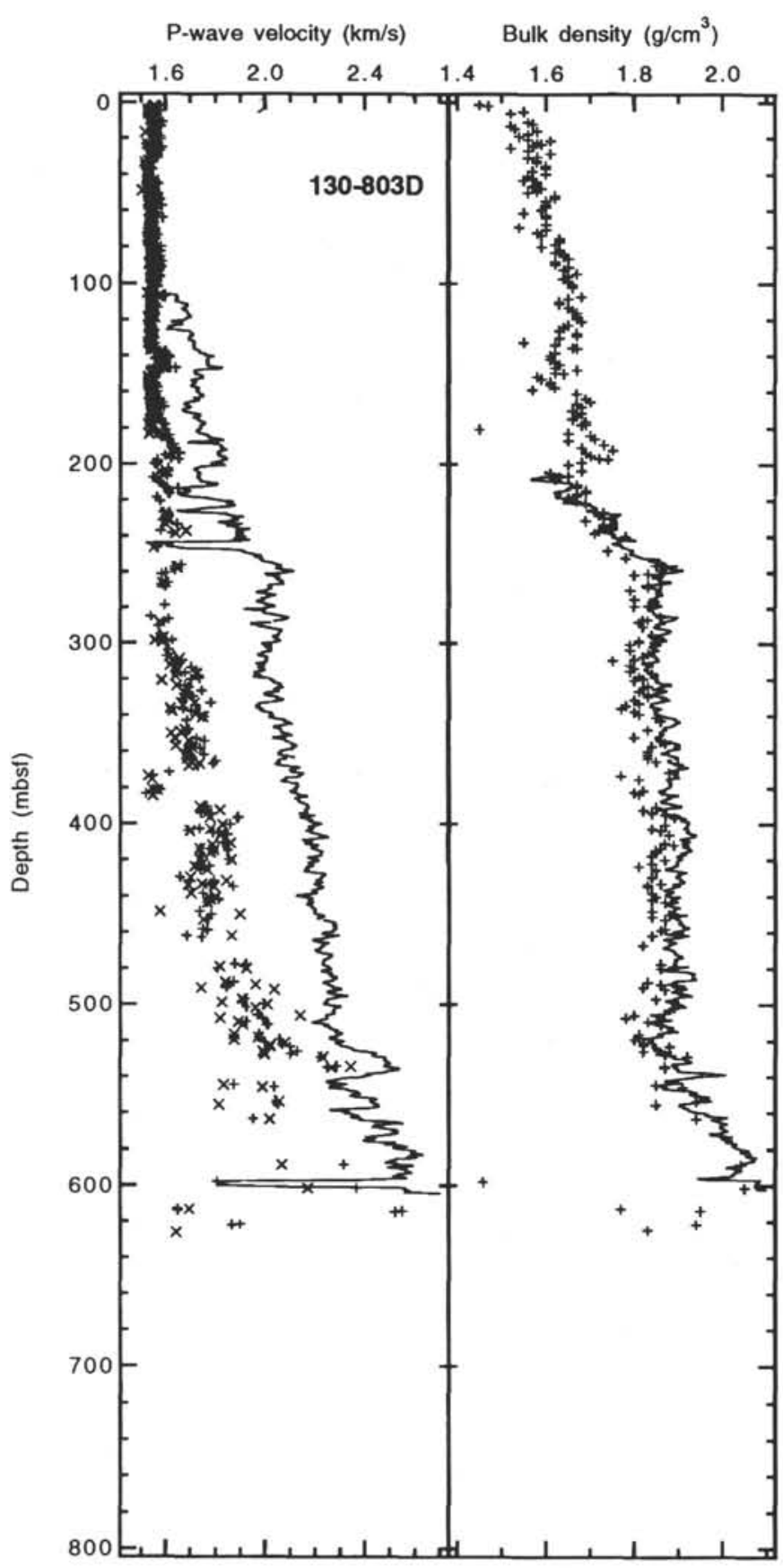

Figure 2 (continued).

to disturbance caused by the coring process or by the expansion of pore fluids, so that sediment rigidity that is a consequence of incipient cementation will be lost. The net consequence in the oozes is a sample that behaves like a sediment suspension that can be modeled according to Wood's equation (Wood, 1941). Samples of the chalks retain some of their rigidity because they are better cemented. They have higher velocity values than do the oozes, but velocity values of chalk samples are still much less than the log measurements. The large scatter in the laboratory data indicates that the effects of sample disturbance in chalks are probably still important. Thus, differences between laboratory and $\log$ velocity measurements appear to result from reductions in the sediment elastic moduli, and the use of porosity rebound to correct laboratory velocities from the Ontong Java Plateau pelagic carbonates is neither appropriate nor effective.

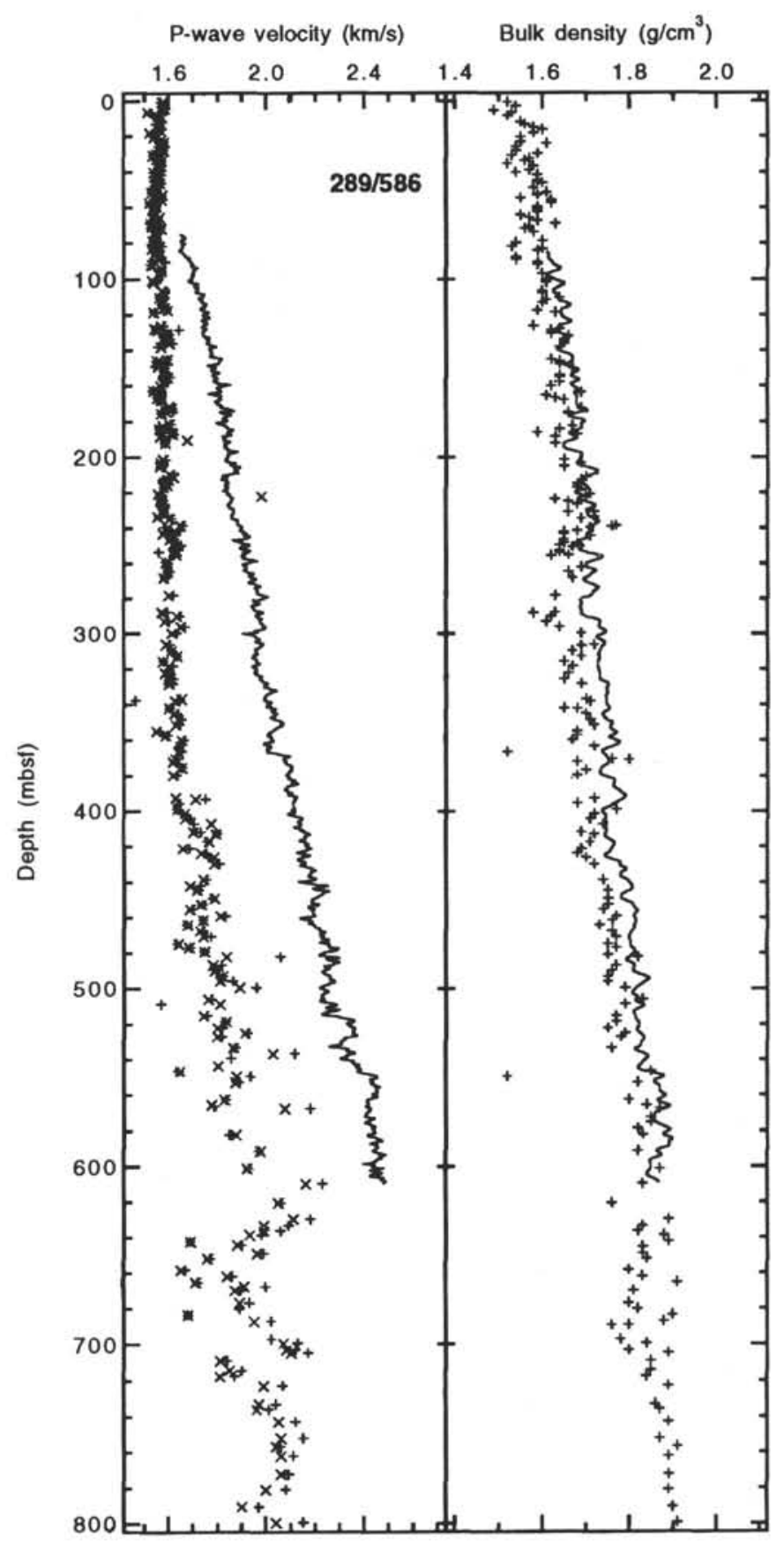

\section{LABORATORY VELOCITIES-DESTINATION IN SITU}

Because the porosity rebound correction to laboratory velocity data is not applicable to pelagic carbonate samples from the Ontong Java Plateau, development of another method for correcting laboratory sonic velocity data to in-situ values in these sediments is highly desirable. We have evaluated two different approaches to the problem of predicting in-situ velocities by examining (1) velocity-porosity relationships and (2) variation of velocity with depth.

\section{Porosity Route}

Inspection of Figure 8 shows that the log data cluster along a diagonal trend and are perhaps suitable for deriving an empirical 

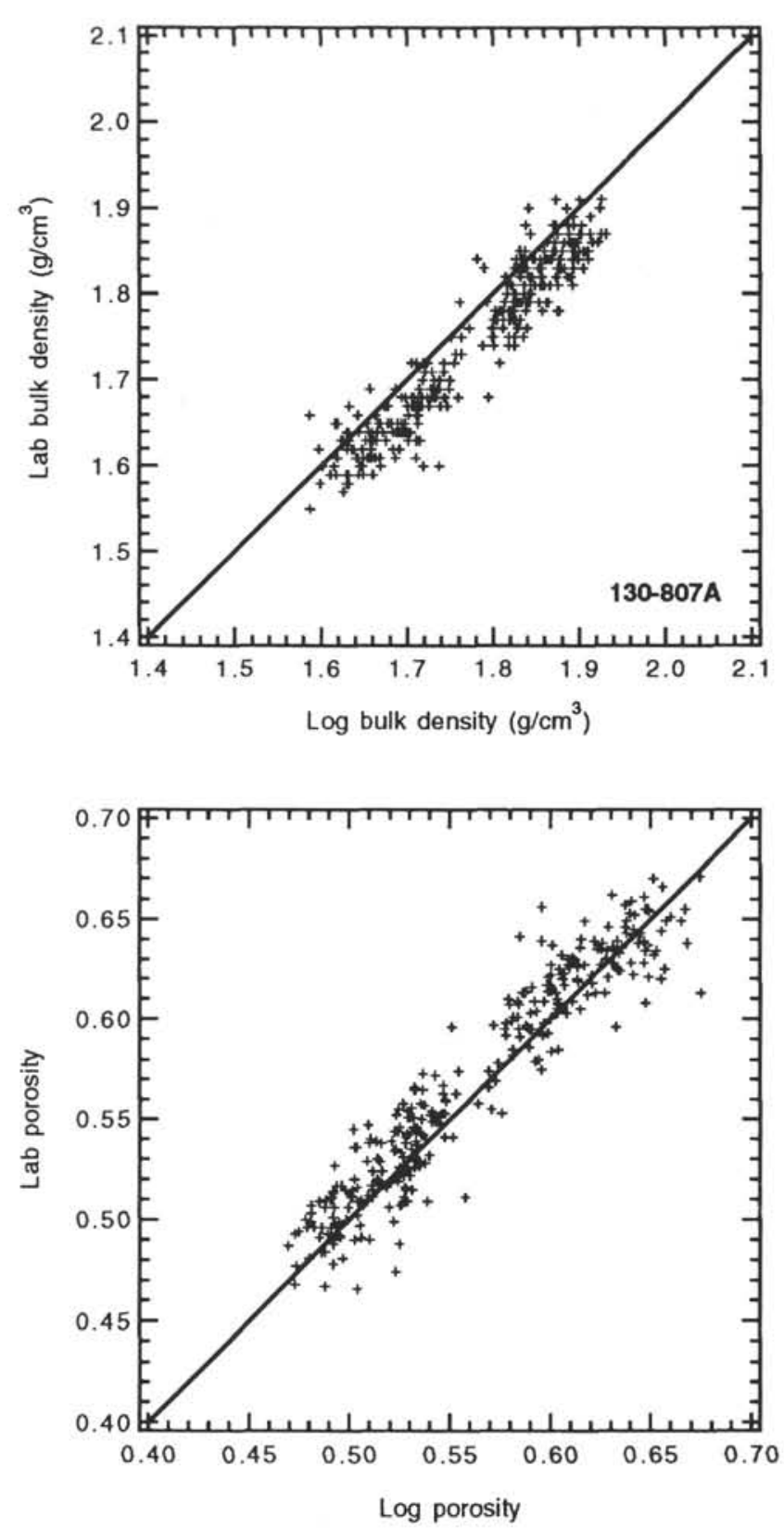

Figure 3. Comparisons of raw laboratory and log measurements of bulk density and porosity from the same sample intervals in Hole 807A. The line corresponds to a 1:1 relationship between the different measurements.

function in terms of velocity and porosity that can be used for correcting laboratory velocities to agree with in-situ logs. Such an empirical correction might prove useful because, as has been seen previously, laboratory porosity measurements appear to be much less susceptible to disturbance than velocity measurements and can also be easily corrected to in-situ values.

Hole 807A logging data from the carbonate oozes and chalks fit reasonably well to a linear regressionn expressed as sonic slowness $\left(1 / V_{p}\right)$. The regression of $V_{p}(\mathrm{~km} / \mathrm{s})$ as a function of fractional porosity $(\phi)$ is given by

$$
\left(1 / V_{p}\right)=1.0672 \phi-0.1156,
$$

and is plotted in Figure 8. As can be seen in Figure 8, this regression will only yield reasonable velocities for porosities between about
0.48 and 0.74 . Beyond this porosity range, the Wood or Wyllie equations appear to be better suited to obtaining in-situ velocities where appropriate.

Implicit to the application of a Hole $807 \mathrm{~A}$ velocity-porosity regression to other data is the assumption that the Hole 807A data are typical of other Ontong Java Plateau sites and pelagic carbonates in general. A comparison of the regression and the Hole 807A data with one of the deeper water Ontong Java Plateau sites, Hole 803D, in Figure 9 reveals that this assumption does not hold true. The Hole $803 \mathrm{D}$ data cluster along a trend parallel to and distinct from the $807 \mathrm{~A}$ data. Use of the Hole 807A regression to correct Hole 803D laboratory velocity measurements would yield much higher "in-situ" velocities than is actually the case. Thus, although porosity appears to be useful for estimating in-situ velocities at a single locality, porosity-based empirical functions from Ontong Java Plateau carbonates are not generally applicable for estimating in-situ sonic velocities at other sites - even if sediment mineralogies are virtually identical to Hole $807 \mathrm{~A}$. The lack of general applicability of the velocity-porosity empirical function may be related to hollow grain effects, observed by Hamilton et al. (1982) for surface samples collected at different water depths on the Ontong Java Plateau, which render porosity a poor predictor of sonic velocity in these sediments.

\section{Depth Route}

A more useful approach to obtaining a correction to laboratory sonic velocity measurements is to examine directly the differences between the laboratory and $\log$ data. As has been seen, the most significant factor affecting laboratory velocities appears to be the reduction of sediment elastic moduli (bulk and shear moduli) resulting from the removal of overburden pressure. Because sediments of the Ontong Java Plateau are homogeneous pelagic carbonates, overburden pressure and differences between laboratory and in-situ sediment elastic moduli may, to a first approximation, be taken as simple functions of depth in a borehole.

Differences between laboratory and log sonic velocity measurements as a function of depth should be a direct consequence of changes in elastic moduli. Log and laboratory velocity differences ( $\log$ - laboratory) from the carbonate oozes and chalks in Hole 807A are shown in Figure 10. Laboratory velocities used to obtain the differences were corrected beforehand for variations in pore-water velocities at in-situ temperatures, pressures, and salinity, using the simplified equation of Medwin (1975). This equation is used here for depths beyond the stated range of applicability, but the error in doing so is trivial $(<3 \mathrm{~m} / \mathrm{s})$ for our purposes. The same temperature relationships are used as for the water density corrections and salinity is assumed to be constant (35\%). The magnitudes of the pore-water velocity corrections to sediment velocities range from about -0.030 $\mathrm{km} / \mathrm{s}$ at the top of Hole $807 \mathrm{~A}$ to $0.015 \mathrm{~km} / \mathrm{s}$ at $800 \mathrm{mbsf}$.

To obtain a function for correcting laboratory velocity data, the $\log$ minus laboratory velocity differences, $\Delta V_{p}(\mathrm{~km} / \mathrm{s})$, were fit to an exponential equation:

$$
\Delta V_{p}=0.646[1-\exp (-0.00219 Z)],
$$

where $Z$ is depth (mbsf). The fit was constrained to give $\Delta V_{p}=0$ for $Z=0$ because only a temperature correction is necessary to achieve an in-situ velocity for sediments at the seafloor (Hamilton, 1971). Applications of the $\Delta V_{p}$ correction will be limited to carbonate-rich oozes and chalks at depths above $800 \mathrm{mbsf}$. This equation gives a reasonably good fit to the $\Delta V_{p}$ results and yields a laboratory velocity correction of $0.5 \mathrm{~km} / \mathrm{s}$ near $700 \mathrm{mbsf}$ (Fig. 10).

Results of the $\Delta V_{p}$ correction to laboratory velocity measurements from Hole $807 \mathrm{~A}$ are compared in Figure 11 with the in-situ log velocities. Also shown are the original uncorrected laboratory velocities. As would be expected for this hole, agreement between log and 
A

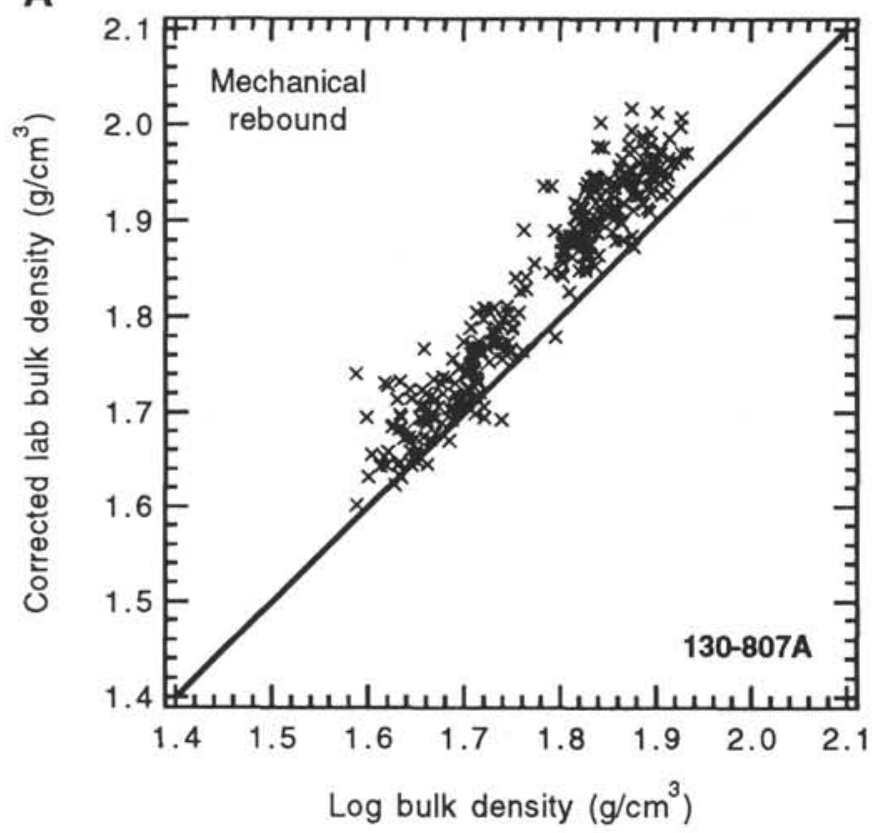

B

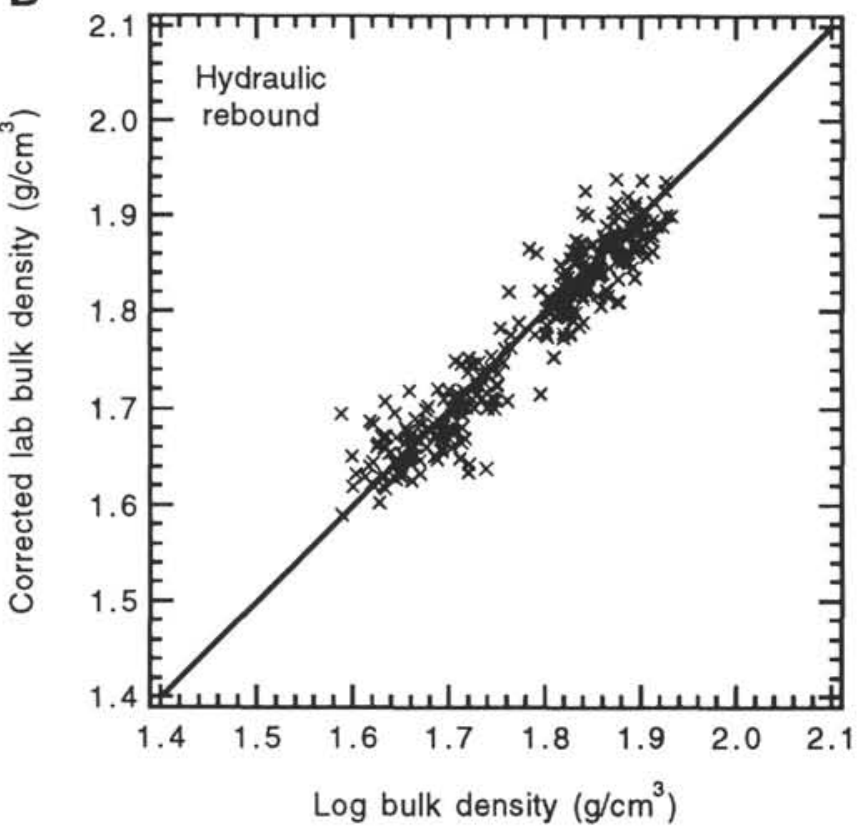

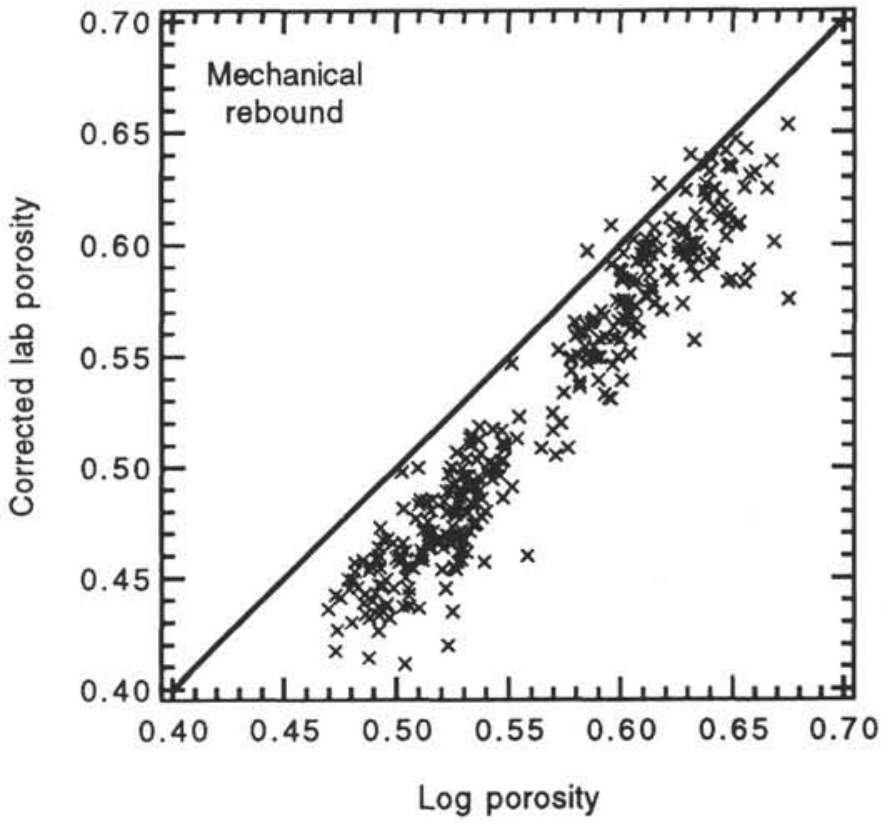

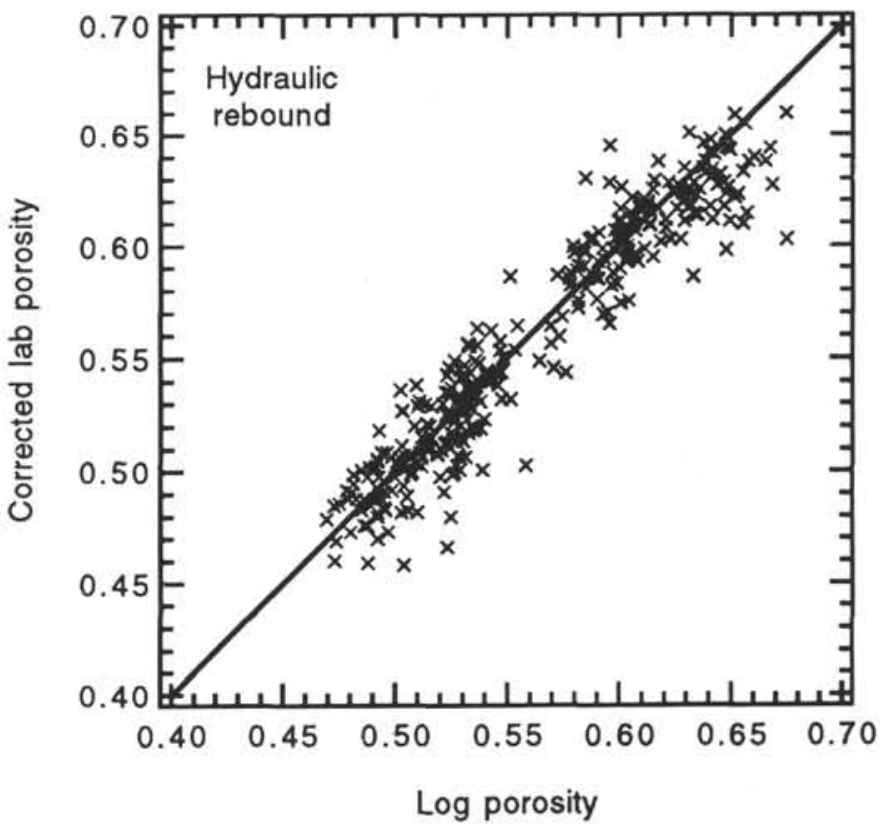

Figure 4. Crossplot comparisons of log measurements with (A) mechanical rebound correction (Hamilton, 1976) and (B) hydraulic rebound correction to laboratory bulk density and porosity from Hole 807A. The line corresponds to a 1:1 relationship between the different measurements.

corrected laboratory velocities is excellent, especially for the oozes. Corrected velocities for chalks show greater scatter about the log velocities than for oozes because variable sample disturbance causes higher levels of "noise" in the chalk velocity measurements.

The Hole $807 \mathrm{~A} \Delta V_{p}$ correction was also used to correct laboratory velocity measurements from Ontong Java Plateau Holes $805 \mathrm{C}$ and 803D, and DSDP Sites 289/586 (Fig. 11). The Hole 806B corrected velocities show similar relations to the log as do the other sites, but they are not presented in Figure 11. For all of these holes, $\Delta V_{p}$-corrected laboratory velocities are in very good agreement with in-situ $\log$ velocities over the entire range of depths. Agreement between corrected laboratory velocities from Site 289 and the log from Site 586 is particularly important because it implies that (1) laboratory measurements, when of reasonably good quality, from older ODP and DSDP legs can be corrected to give useful estimates of in-situ values; and (2) that there are no measurably significant systematic biases in Leg $130 \mathrm{log}$ or laboratory data that would limit general application of the $\Delta V_{p}$ correction.

A factor that should be considered when applying the $\Delta V_{p}$ correction is the amount of sample disturbance from a particular hole relative to samples from Hole $807 \mathrm{~A}$ that define the $\Delta V_{p}$ correction. More disturbed samples, which typically have lowered velocities, 

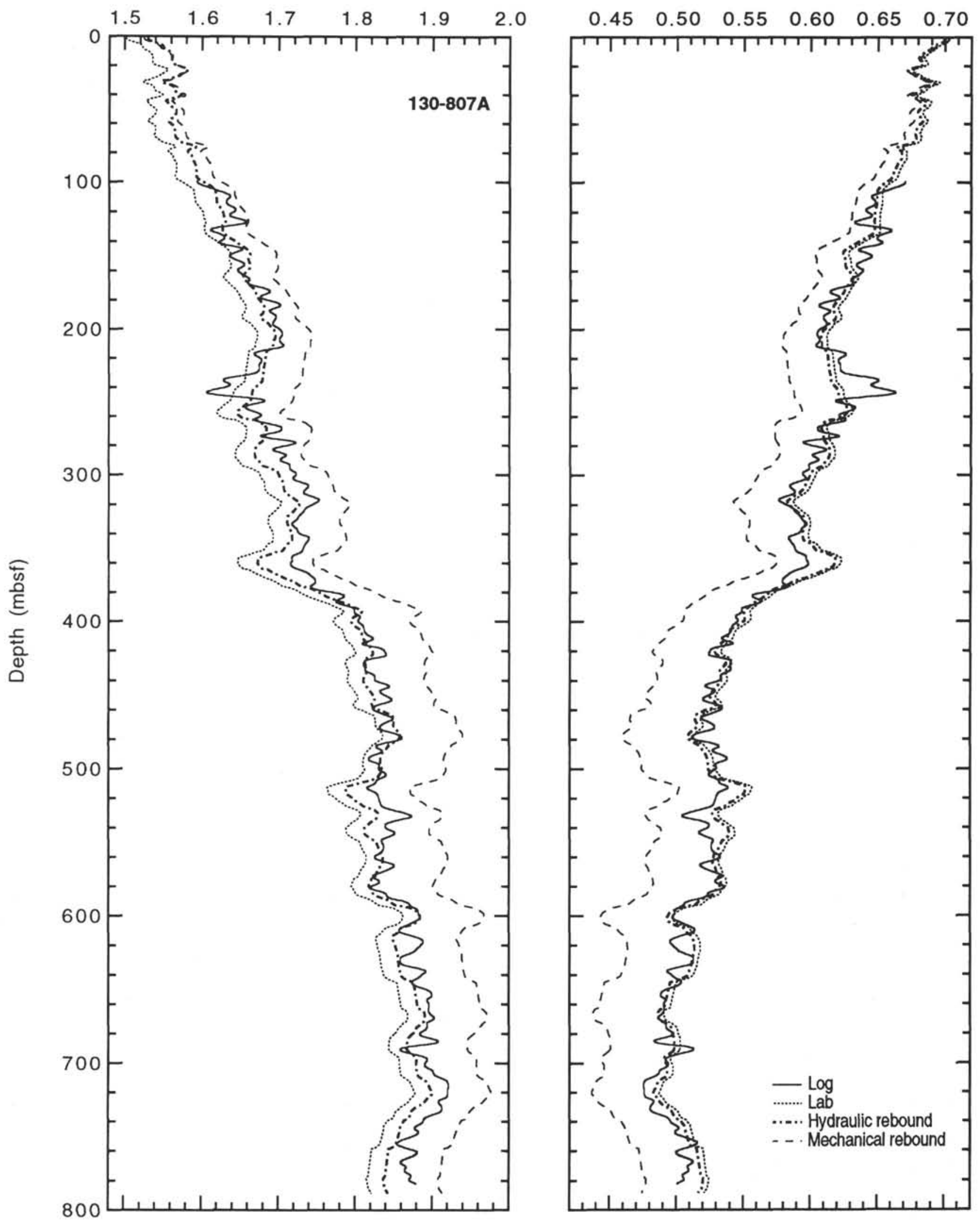

Figure 5. Downhole comparisons of uncorrected laboratory and log data with corrections to laboratory results for hydraulic and mechanical rebound (Hamilton, 1976 ) in measurements of bulk density and porosity from Hole 807A. Data were smoothed using a Gaussian filter. 

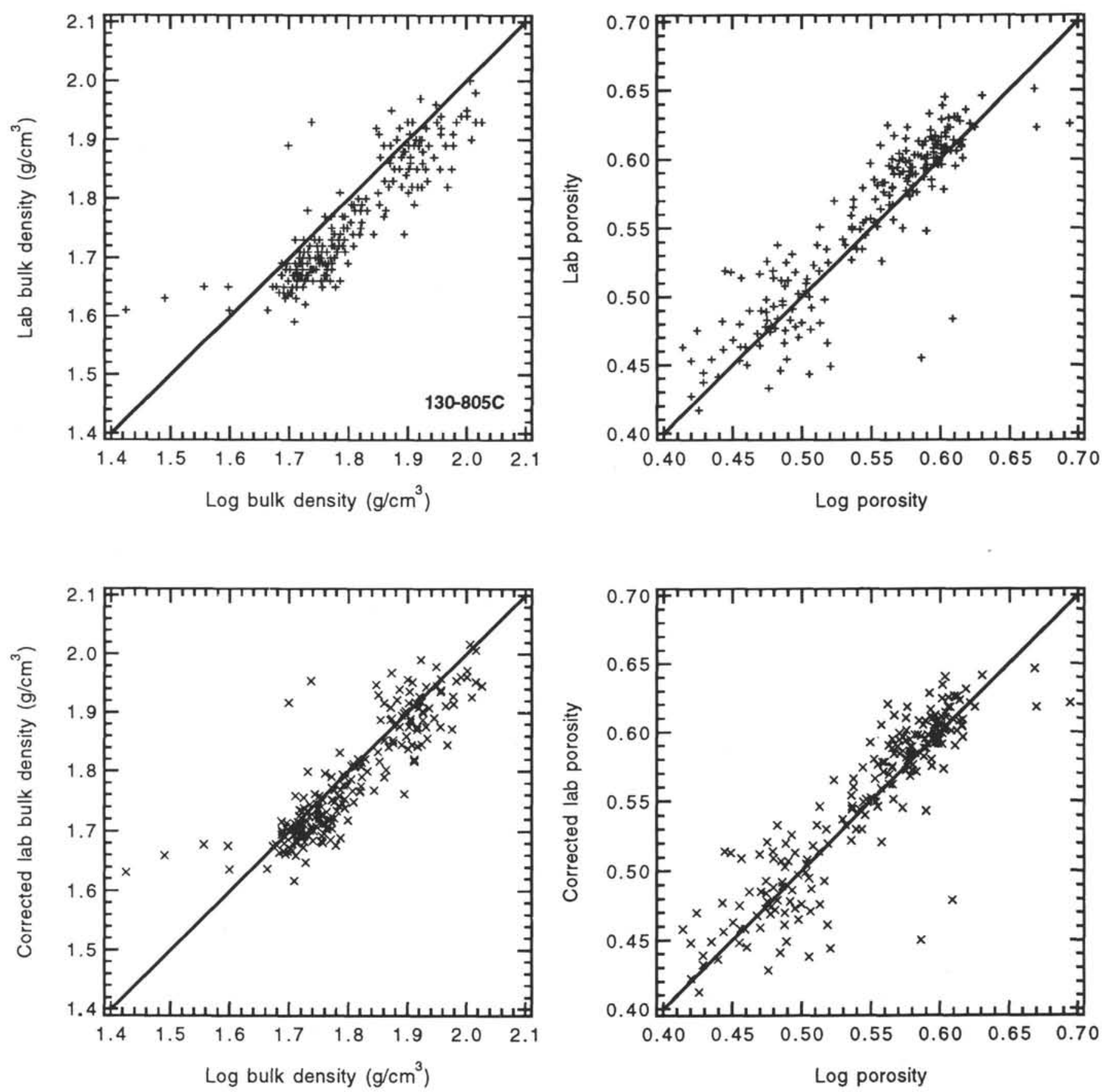

Figure 6. Comparisons of laboratory and log measurements of bulk density and porosity from Hole 805C. A. Uncorrected laboratory measurements. B. Laboratory measurements corrected for pore-water hydraulic rebound. The line corresponds to a 1:1 relationship between the $\log$ and laboratory measurements.

will yield underestimates of the in-situ velocity, whereas less disturbed (or more lithified) samples will overestimate the in-situ velocity. These effects may explain why the corrected laboratory velocities differ slightly from the in-situ log velocities below about $240 \mathrm{mbsf}$ in Hole $805 \mathrm{C}$ and below about $480 \mathrm{mbsf}$ in Hole 803D (Fig. 11). It is interesting to note that in Hole $805 \mathrm{C}$ the velocity offset occurs at the approximate depth interval where the method of sediment coring was switched from the advanced hydraulic piston corer (APC) to the extended core barrel corer (XCB) (Kroenke, Berger, Janecek, et al., 1991).

At Sites 289/586 the corrected laboratory velocities are systematically about $0.05 \mathrm{~km} / \mathrm{s}$ less than the $\log$ velocities; this offset may reflect a higher degree of disturbance of the Site 289 samples, which were recovered by rotary drilling (Shipboard Scientific Party, 1975). Alternatively, the offset may result from slight differences between the sediments at Sites 289 and 586, which were drilled about $1.3 \mathrm{~km}$ apart.

Although we assumed in our discussion of the $\Delta V_{p}$ correction that depth serves as a proxy for effective pressure, downhole depth is also related to age of the sediments. Evaluation of a $\Delta V_{p}$-age correction to Ontong Java Plateau sediments reveals that it is not generally applicable. In addition, were sediment age a significant factor responsible for differences between log and laboratory velocity measurements, the Hole $807 \mathrm{~A} \Delta V_{p}$-depth correction would not pertain to other sites 

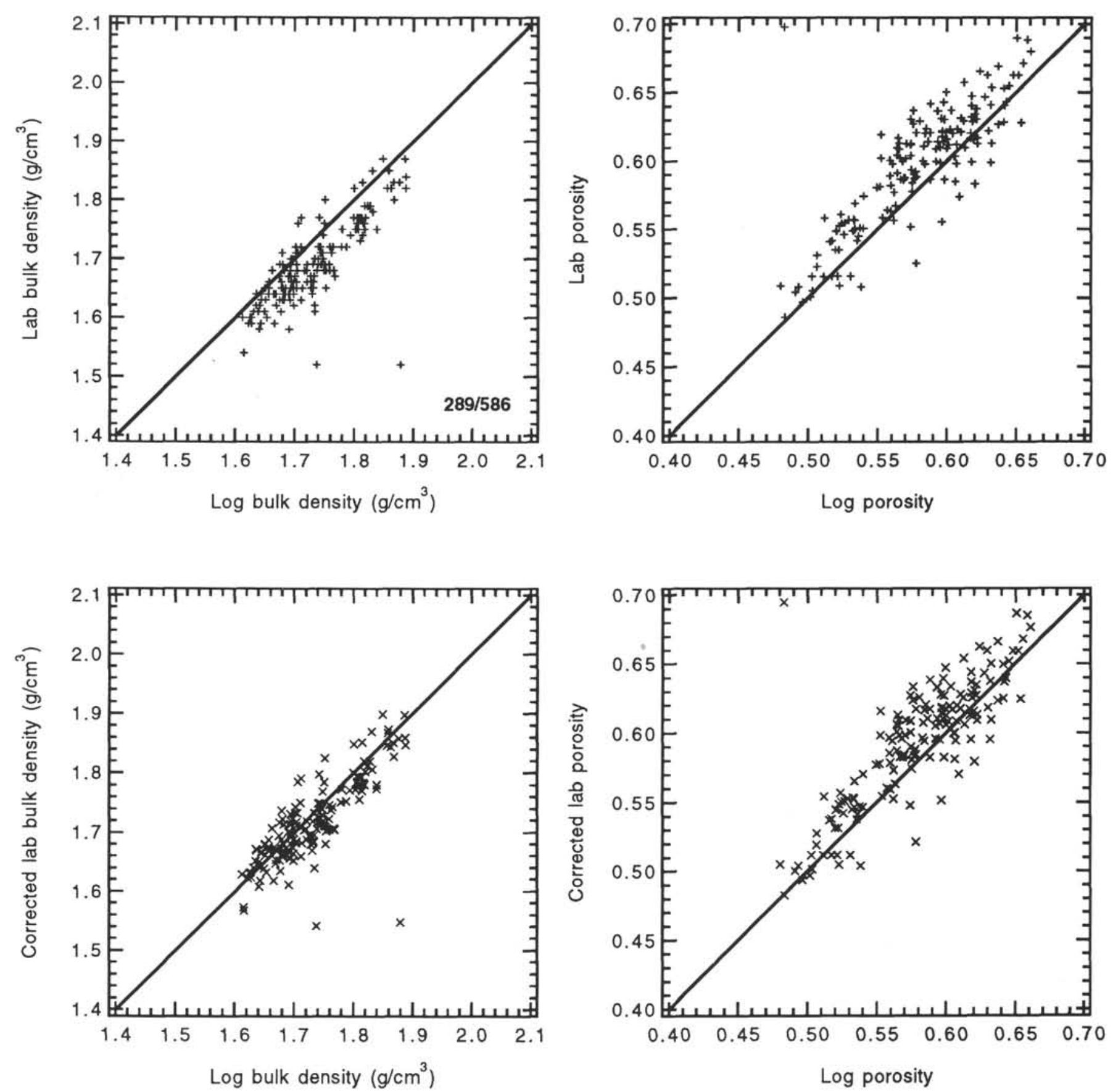

Figure 7. Comparisons of laboratory and log measurements of bulk density and porosity from Sites 289/586. A. Raw laboratory measurements. B. Laboratory measurements corrected for pore-water hydraulic rebound. The line corresponds to a 1:1 relationship between the log and laboratory measurements.

because of differences in sedimentation rates. But as we have shown, the $\Delta V_{p}$-depth correction works very well for all of the Ontong Java Plateau sites (Fig. 11) and, as a consequence, sediment age does not appear to be an important factor to consider. Depth-related reductions of effective pressure and the resulting changes in the sediment elastic moduli are primarily responsible for the differences between laboratory and in-situ log velocity data.

\section{CONCLUSIONS}

The compositional homogeneity of pelagic carbonate oozes and chalks recovered from the Ontong Java Plateau during Leg 130 and previous DSDP legs and the excellent suite of logging and shipboard laboratory physical properties measurements of these sediments have facilitated our detailed comparisons of in-situ logging data with laboratory measurements. Results of these log-laboratory comparisons have revealed a number of significant insights about coring-related disturbance of sediment samples.

Sediment porosity rebound in laboratory samples of the magnitude identified by Hamilton (1976) was not observed in the Ontong Java Plateau pelagic carbonates. Discrepancies between laboratory and log bulk density and porosity measurements are very small and constant over a great range of depths. A simple hydraulic rebound correction that accounts for expansion of pore fluids after removal from in-situ 


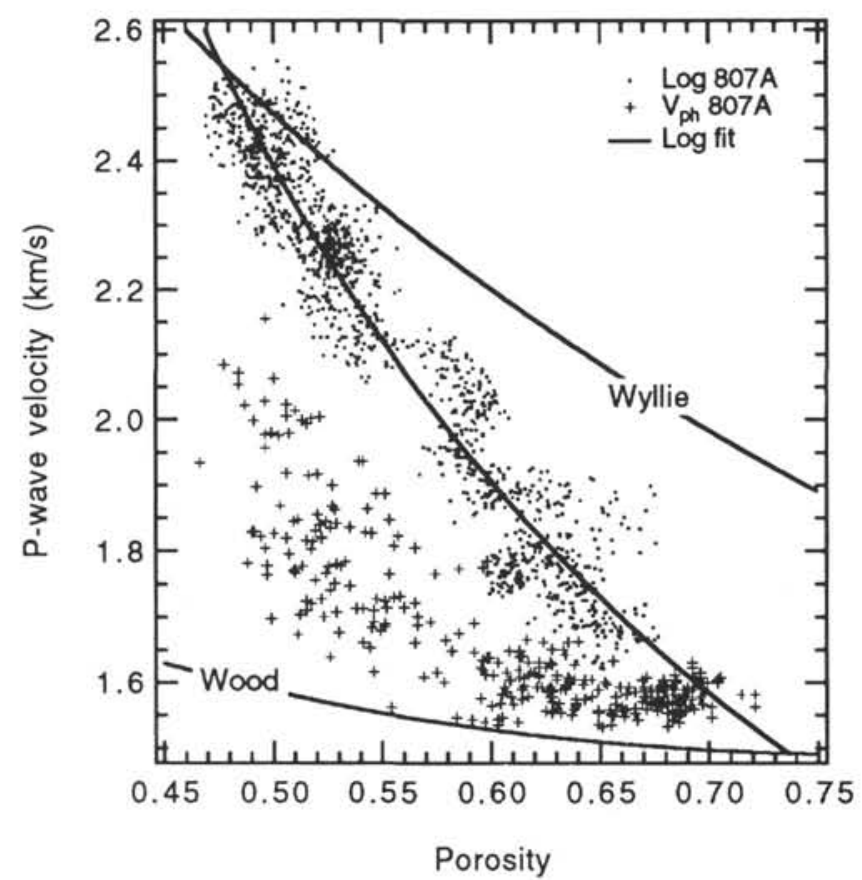

Figure 8. Log and laboratory velocities plotted vs. porosity, Hole 807A. No corrections were applied to the laboratory data. The curve through the logging data represents a linear regression (Eq. 2) to these measurements in terms of sonic slowness $\left(1 / V_{p}\right)$. The Wyllie time-average (Wyllie et al., 1956) and Wood (1941) equations are also shown for reference.

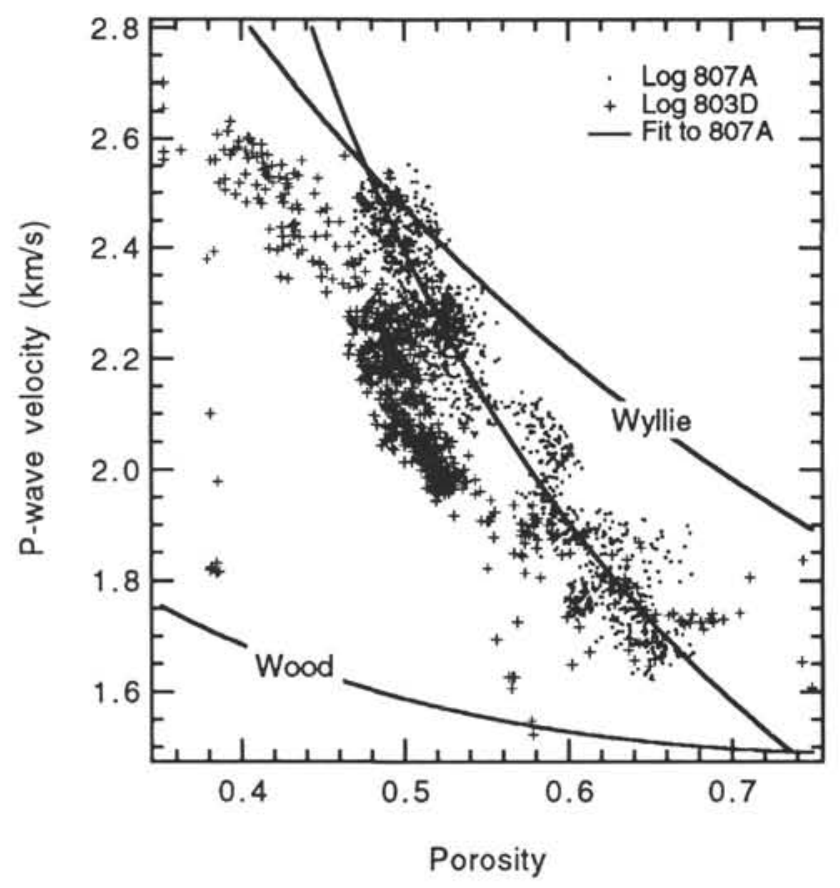

Figure 9. Log velocities from Holes $803 \mathrm{D}$ and $807 \mathrm{~A}$ plotted against porosity. The fit (Eq. 2) to the Hole 807A data does not fit the Hole 803D data because the Hole $803 \mathrm{D}$ data are offset to lower porosity and/or velocity values relative to Hole 807A data. The Wyllie time-average (Wyllie et al., 1956) and Wood (1941) equations are also shown for reference. conditions resolves these discrepancies. If rebound of the sediment mineral matrix occurs in Ontong Java Plateau pelagic carbonates, it must be very small and not much greater than $1 \%-2 \%$.

A porosity rebound correction cannot be validly used to adjust laboratory sonic velocity measurements to obtain in-situ velocities in pelagic carbonate sediments. For a rebound correction to work, laboratory and in-situ data must occupy the same fields on plots of velocity vs. porosity. Such plots for Ontong Java Plateau data reveal that in-situ logging measurements and laboratory data define distinct and separate trends with little overlap between the two types of measurement. Thus, application of a rebound correction to laboratory porosity data will not yield correct in-situ porosities nor can it be applied to correct laboratory velocity data to in-situ values.

A velocity correction derived from log velocity-porosity relationships does not appear to be generally useful for correcting laboratory measurements to in-situ velocity values in pelagic carbonates. Velocity-porosity trends for Holes 807A and 803D are significantly different even though sediments from both holes have virtually identical mineralogies. These differences appear to result from varying abundances of hollow foraminifer grains that complicate porosity relationships in the Ontong Java Plateau carbonates.

Laboratory sonic velocity measurements are readily corrected to in-situ values using a relationship based on the differences between log and laboratory velocities with depth (Eq. 3). This $\Delta V_{p}$ depth correction to laboratory velocities implies that changes in sediment elastic moduli, resulting from the reduction of overburden pressure after coring, are the most significant factors affecting laboratory velocity measurements. The $\Delta V_{p}$ correction to laboratory velocity data appears to be generally applicable to pelagic carbonate oozes and chalks of the Ontong Java Plateau, regardless of depth of deposition or age.

\section{ACKNOWLEDGMENTS}

We would like to thank Richard Bachman and an anonymous reviewer for critically reviewing this manuscript. The DSV used during Leg 130 was loaned by the Départment de Géologie Dynamique, Université Pierre et Marie Curie and developed with funding from INSU/CNRS to Y. Lancelot. This research was supported by funding from JOI/USSAC and ONR grant N0014-90-J-1631. This is School of Ocean and Earth Science and Technology Contribution No. 2802.

\section{REFERENCES}

Bachman, R.T., 1984. Intratest porosity in foraminifera. J. Sediment. Petrol., $54: 257-262$.

Berger, W.H., Johnson, T.C., and Hamilton, E.L., 1977. Sedimentation on Ontong Java Plateau: observations on a classic "carbonate monitor." In Andersen, N.R., and Malahoff, A. (Eds.), The Fate of Fossil Fuel CO $\mathrm{CO}_{2}$ in the Oceans: New York (Plenum), 534-567.

Berger, W.H., and Mayer, L.A., 1978. Deep-sea carbonates: acoustic reflectors and lysocline fluctuations. Geology, 6:11-15.

Boyce, R.E., 1976a. Definitions and laboratory techniques of compressional sound velocity parameters and wet-water content, wet-bulk density, and porosity parameters by gravimetric and gamma-ray attenuation techniques. In Schlanger, S.O., Jackson, E.D., et al., Init. Repts. DSDP, 33: Washington (U.S. Govt. Printing Office), 931-958.

$-1976 \mathrm{~b}$. Sound velocity-density parameters of sediment and rock from DSDP drill sites $315-318$ on the Line Island Chain, Manihiki Plateau, and Tuamotu Ridge in the Pacific Ocean. In Schlanger, S.O., Jackson, E.D., et al., Init. Repts. DSDP, 33: Washington (U.S. Govt. Printing Office), 695-728.

1980. Determination of the relationships of electrical resistivity, sound velocity, and density/porosity of sediment and rock by laboratory techniques and well logs from Deep Sea Drilling Project Sites 415 and 416 off the coast of Morocco. In Lancelot, Y., Winterer, E.L., et al., Init. Repts. DSDP, 50: Washington (U.S. Govt. Printing Office), 305-318.

Broecker, W.S., Spencer, D.W., and Craig, H., 1982. GEOSECS Pacific Expedition (Vol. 3): Hydrographic Data, 1973-1974: Washington (U.S. Govt. Printing Office). 
Fulthorpe, C.S., Schlanger, S.O., and Jarrard, R.D., 1989. In situ acoustic properties of pelagic carbonate sediments on the Ontong Java Plateau. $J$. Geophys. Res., 94:4025-4032.

Hamilton, E.L., 1965. Sound speed and related physical properties of sediments from experimental MOHOLE (Guadalupe Site). Geophysics, 30:257-261.

, 1971. Prediction of in-situ acoustic and elastic properties of marine sediments. Geophysics, 36:266-284.

- 1976. Variations of density and porosity with depth in deep-sea sediments. J. Sediment. Petrol., 46:280-300.

, 1979. Sound velocity gradients in marine sediments. J. Acoust. Soc. Am., 65:909-922.

Hamilton, E.L., Bachman, R.T., Berger, W.H., Johnson, T.C., and Mayer, L.A., 1982. Acoustic and related properties of calcareous deep-sea sediments. $J$. Sediment. Petrol., 52:733-753.

Hempel, P., Mayer, L., Taylor, E., Bohrmann, G., and Pittenger, A., 1989. The influence of biogenic silica on seismic lithostratigraphy at ODP Sites 642 and 643, eastern Norwegian Sea. In Eldholm, O., Thiede, J., Taylor, E., et al., Proc. ODP, Sci. Results, 104: College Station, TX (Ocean Drilling Program), 941-951.

Hurley, M.T., and Hempel, P., 1990. Porosity and velocity vs. depth and effective stress in carbonate sediments. In Duncan, R.A., Backman, J., Peterson, L.C. et al., Proc. ODP, Sci. Results, 115: College Station, TX (Ocean Drilling Program), 773-777.

Jarrard, R.D., Dadey, K.A., and Busch, W.H., 1989. Velocity and density of sediments of Eirik Ridge, Labrador Sea: control by porosity and mineralogy. In Srivastava, S.P., Arthur, M., et al., Proc. ODP. Sci. Results, 105 ; College Station, TX (Ocean Drilling Program), 811-835.

Johnson, T.C., Hamilton, E.L., Bachman, R.T., and Berger, W.H., 1978. Sound velocities in calcareous oozes and chalks from sonobuoy data: Ontong Java Plateau, western equatorial Pacific. J. Geophys. Res., 83:283-288.

Johnson, T.C., Hamilton, E.L., and Berger, W.H., 1977. Physical properties of calcareous ooze: control by dissolution at depth. Mar. Geol., 24:259-277.

Kim, D.-C., Manghnani, M.H., and Schlanger, S.O., 1985. The role of diagenesis in the development of physical properties of deep-sea carbonate sediments. Mar. Geol., 69:69-91.

Kroenke, L.W., Berger, W.H., Janecek, T.R., et al., 1991. Proc. ODP, Init. Repts., 130: College Station, TX (Ocean Drilling Program).
Mayer, L.A., Courtney, R.C., and Moran, K., 1987. Ultrasonic measurements of marine sediment properties. Proc. Oceanogr., 87,1:139.

Mayer, L.A., Shipley, T.H., Theyer, F., Wilkens, R.H., and Winterer, E.L., 1985. Seismic modeling and paleoceanography at Deep Sea Drilling Project Site 574. In Mayer, L., Theyer, F., Thomas, E., et al., Init. Repts. DSDP, 85: Washington (U.S. Govt. Printing Office), 947-970.

Medwin, H., 1975. Speed of sound in water: a simple equation for realistic parameters. J. Acoust. Soc. Am., 58:1318-1319.

Milholland, P., Manghnani, M.H., Schlanger, S.O., and Sutton, G.H., 1980. Geoacoustic modeling of deep-sea carbonate sediments. J. Acoust. Soc. Am., 68:1351-1360.

Millero, F.J., Chen, C.-T., Bradshaw, A., and Schleicher, K., 1980. A new high pressure equation of state for seawater. Deep-sea Res., Pt. A, 27:255-264.

Millero, F.J., and Poisson, A., 1981. International one-atmosphere equation of state of seawater. Deep-sea Res., Pt. A, 28:625-629.

Nobes, D.C., Mwenifumbo, C.J., Mienert, J., and Blangy, J.P., 1991. The problem of porosity rebound in deep-sea sediment cores: a comparison of laboratory and in-situ physical-property measurements, Site 704, Meteor Rise. In Ciesielski, P.F., Kristoffersen, Y., et al., Proc. ODP, Sci. Results, 114: College Station, TX (Ocean Drilling Program), 711-716.

Shipboard Scientific Party, 1975. Site 289. In Andrews, J.E., Packham, G., et al., Init. Repts. DSDP, 30: Washington (U.S. Govt. Printing Office).

, 1986. Site 586. In Moberly, R., Schlanger, S.O., et al., Init. Repts. DSDP, 89: Washington (U.S. Govt. Printing Office).

Shipley, T.H., 1983. Physical properties, synthetic seismograms, and seismic reflections: correlations at Deep Sea Drilling Project Site 534, BlakeBahama Basin. In Sheridan, R.E., Gradstein, F.M., et al., Init. Repts. DSDP, 76: Washington (U.S. Govt. Printing Office), 653-666.

Skinner, B.J., 1966. Thermal expansion. Mem. - Geol. Soc. Am., 97:75-96.

Wood, A.B., 1941. A Textbook of Sound: London (G. Bell and Sons).

Wyllie, M.R.J., Gregory, A.R., and Gardner, G.H.F., 1956. Elastic wave velocities in heterogeneous and porous media. Geophysics, 21:41-70.

Date of initial receipt: 20 February 1991

Date of acceptance: 28 April 1992

Ms 130B-048 


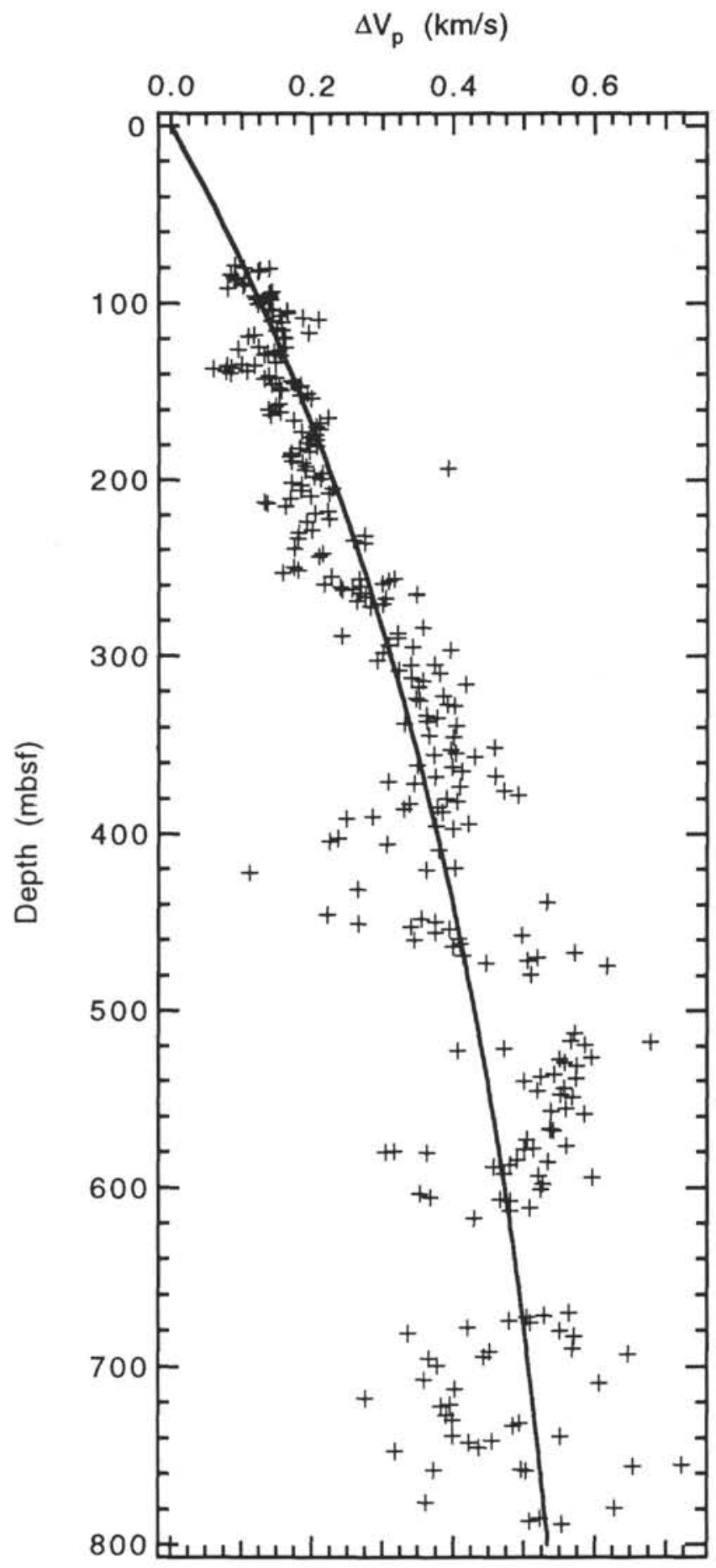

Figure 10. Differences (log - lab) between laboratory $\left(V_{p h}\right)$ and $\log$ velocity measurements as a function of depth in Hole 807A. Laboratory velocities were corrected beforehand for effects of temperature and pressure on pore-water velocities (see text for discussion). The curve is an exponential fit to the $\Delta V_{p}$ data given by Equation 3 . 


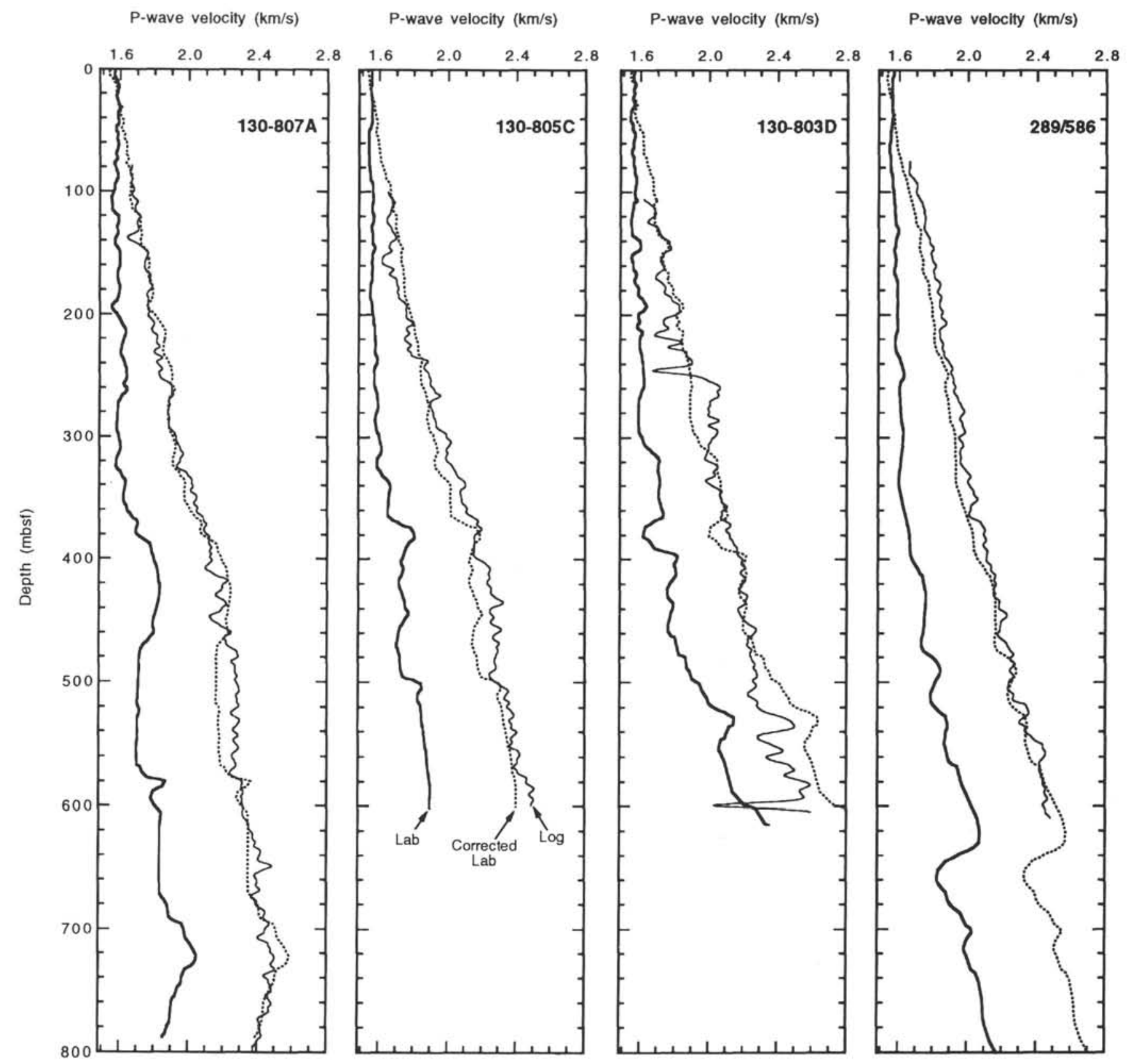

Figure 11. Downhole variations in uncorrected laboratory velocity, laboratory velocity corrected using the $\Delta V_{p}$-depth correction (Eq. 3), and log velocity from Holes 807A, 805C, 803D, and Sites 289/586. Data were smoothed using a Gaussian filter. 